\title{
Practicing Safe Sects
}

\author{
We are all atheists about most of the gods that humanity has ever believed \\ in. Some of us just go one god further. \\ RICHARD DAWKINS
}

For most of human history, theism - like racism, classism, and sexism - played an important role in the emergence of ever more complex and expansive forms of societal organization. The evolution and transmission of the perceptive and affiliative biases that foster religious reproduction facilitated the psychological internalization and political institutionalization of personal and social categories even - or especially - when those categories had the effect of repressing or oppressing the needs and drives of some individuals. Shared imaginative engagement with axiological relevant supernatural agents effectively held human beings together in increasingly differentiated cultural coalitions, strengthening their capacity for in-group cooperation and coordination.

In this sense, not practicing safe sects - bearing gods in mind and culture "worked." As we have seen throughout this book, however, there is another sense in which (re)producing supernatual conceptions is unsafe. The mutual intensification of superstitious beliefs and segregative practices that strengthens relationships within a religious coalition also covertly cements prejudice against and antagonism toward members of other religious (or non-religious) coalitions. This is the political tragedy of overtly religious attempts to promote peace: struggling against the effects of sociographic prudery (e.g., aggressive behaviors toward those who practice different supernatural rituals) while simultaneously embracing and encouraging anthropomorphic promiscuity (e.g., idiosyncratic beliefs about the role of in-group gods in shaping society) usually only makes things worse because the latter surreptitiously reinforces the former (and vice versa).

All of this is complicated by the psychological tragedy that the mental dissolution of the gods imaginatively engaged by the religious coalition with which one identifies can initially have a dis-integrating effect on one's sense of

(C) F. LERON SHULTS, 2018 DOI 10.1163/9789004360952_013

This is an open access chapter distributed under the terms of the CC BY-NC-ND 4.o license. Shults - 9789004360952 
self. ${ }^{1}$ This is why having "the talk" about religious reproduction requires sensitivity and patience. Shaming people for wanting to bear gods only makes them angry or more anxious, which further activates the defense mechanisms of theistic bias. I have not tried to hide my god-dissolving intentions in the contraceptive essays of this book. The goal of the central chapters was to demonstrate the anaphrodisiacal effect of scientific and philosophical perspectives on religious reproduction. It turned out that even theology - at least when it followed its iconoclastic trajectory - had a role to play in contesting the evolved biases that engender shared imaginative engagement with coalition-favoring disembodied intentional forces.

On the other hand, it is also important to be clear and straightforward when discussing the consequences of "doing it." Religion did indeed promote the kind of small-group cohesion Homo sapiens needed to survive and thrive as they hunted and gathered in the upper Paleolithic. Today, however, most human beings live in large-scale, literate states governed by complex legal and political structures.

In this very different social context, the strong cohesion that religion promotes is of much less benefit to most of us than it was to the inhabitants of the pre-Neolithic world. But the intolerance and hostility that religion promotes toward out-groups are harmful and threatening to us all.... The benefits of strong social cohesion that religion engenders may at one time have outweighed the costs entailed by out-group intolerance and conflict, but this is likely no longer the case. ${ }^{2}$

I have argued that it is definitely no longer the case that engaging in religious sects is a viable strategy for survival, at least if we are concerned about the wellbeing of the whole human race (and other species that share our ecologically fragile global habitat), and not merely with our own in-group.

Like unfettered population growth in the natural world, the continued expansion of the supernatural population in the human Imaginarium negatively impacts all of us. It may seem like the problem lies primarily in the astonishing fertility of god-bearing conservative groups, including my own religious family of origin (American evangelicalism). Liberal Christians sometimes roll their

1 For a fuller analysis of other senses in which interreligious dialogue is "tragic," see Chapter 5 of Theology after the Birth of God.

2 Clarke et al., "Religion, Intolerance, and Conflict: Practical Implications for Social Policy," in Religion, Intolerance, and Conflict: A Scientific and Conceptual Investigation ed. Clarke et al. (Oxford: Oxford University Press, 2013), 272. Emphasis added. 
eyes at the way in which conservatives flip-flop between attributing events to God or Satan (depending on the nature of the outcome). ${ }^{3}$ However, progressive believers are just as susceptible to dissonance-reducing biases that lead them to project their own moral values onto the most salient supernatural agent of their in-group: an imagined contemporary Jesus. ${ }^{4}$

In its own way, religious liberal permissivism is just as problematic as religious conservative fertility. Challenging literalistic and xenophobic interpretations of holy texts is a good thing, but continuing to encourage participation in religious sects and reflection on the rehabituation of supernatural symbols only fuels the very biases about which liberals are so perplexed. Insofar as they fail to contest or challenge theistic credulity and conformity biases, and go on promoting or protecting religiously sectarian divisions of humanity, progressives are undermining their own efforts to fight racism, classism, sexism and other forms of prejudice and oppression. ${ }^{5}$ This is why I have spent so much energy in earlier chapters on unveiling the hidden reciprocity that reinforces the theogonic mechanisms of anthropomorphic promiscuity and sociographic prudery.

Along the way, however, we have occassionally had the opportunity to observe the inverse (and more overt) operation of the theolytic mechanisms of anthropomorphic prudery and sociographic promiscuity (see Figure 2, Chapter 1, p. 64), as well as the effect of these iconoclastic forces in science, philosophy, and (to some extent) theology. In this final chapter, I discuss more empirical evidence for - and offer more philosophical reflections on the implications of - the reciprocal reinforcement of these "naturalistic" and "secularistic" tendencies. The central sub-sections, which make up the bulk of the chapter, describe the way in which these mechanisms promote the practice of "safe sects." The concluding sub-section introduces a relatively new methodology that can facilitate our evaluation of hypotheses about - and policies for altering - the dynamics of complex adaptive social systems. First, however, it is important to acknowledge and respond to one of the most common questions raised in reaction to theogonic reproduction theory.

3 Ray et al., "Attributions to God and Satan About Life-Altering Events," Psychology of Religion and Spirituality 7 , no. 1 (2015).

4 Ross et al., "How Christians Reconcile Their Personal Political Views and the Teachings of Their Faith: Projection as a Means of Dissonance Reduction," Proceedings of the National Academy of Sciences 109, no. 10 (2012).

5 See, e.g., the analysis of Sumerau, "'Some of Us Are Good, God-Fearing Folks: Justifying Religious Participation in an LG B T Christian Church," Journal of Contemporary Ethnography 46, no. 1 (2017). 


\section{But Isn't “Religion” Supposed to be Good for Us?}

In the early part of the 2oth century, much of the scholarship on religion in the social sciences in general, and perhaps psychology and sociology in particular, focused on its negative effects. By the 196os, many (if not most) of the leading lights in the relevant disciplines more or less openly criticized religion and anticipated its dissolution. The "return of religion" in the 1970s and 1980s (most obvious in the growth of fundamentalism in the United States and the Middle East) led many to reconsider. Perhaps religion is here to stay. Perhaps it is even good for us. A surge of interest in "positive" psychology in the 1990s had a profound effect on the social scientific study of religion, producing a wealth of studies that emphasized the apparent health benefits of religion and spirituality. ${ }^{6}$ If religion makes us feel good - and act well - then why keep criticizing it?

First, it is important to be clear about what exactly we think is (or is not) supposed to be good for us. The term "religion" is in scare quotes in the title of the sub-heading above as a reminder of the definitional problems discussed briefly in Chapter 1. Religion is sometimes fuzzily defined in relation to, or even conflated with, qualities or behaviors like searching for meaning, having a worldview, feeling culturally connected, attending to the beauty of the universe, reflecting on ultimate concerns, or acting kindly toward others. Such things may very well be good for us, but the failure to offer operationalizable definitions of religion, to distinguish it from other salutogenic traits, or to clarify which facets of "religiosity" are being measured, leads to muddled claims about its alleged benefits. ${ }^{7}$ For the purposes of this final chapter, I will continue to focus on the set of statistically measurable features that have captured our interest throughout this book: those related to shared imaginative engagement with axiologically relevant supernatural agents.

Is "religion" - in this sense - "good for us?" The second point to make is that engaging in religious sects has indeed had the effect of making (some) people

6 For an introduction to this literature, see Joseph et al., "Positive Psychology, Religion, and Spirituality," Mental Health, Religion \& Culture 9, no. 3 (2006). For a recent example, see Boden, "Supernatural Beliefs: Considered Adaptive and Associated with Psychological Benefits," Personality and Individual Differences 86 (2015): 227.

7 For additional analysis of the problems with conflating "religion" with other traits, see Schuurmans-Stekhoven, "Are We, like Sheep, Going Astray: Is Costly Signaling (or Any Other Mechanism) Necessary to Explain the Belief-as-Benefit Effect?" Religion, Brain \& Behavior 7, no. 3 (2016), and Schuurmans-Stekhoven, "As a Shepherd Divideth His Sheep from the Goats': Does the Daily Spiritual Experiences Scale Encapsulate Separable Theistic and Civility Components?" Social Indicators Research 110, no. 1 (2013). See also Lechner et al., "Exploring the Stress-Buffering Effects of Religiousness in Relation to Social and Economic Change: Evidence From Poland," Psychology of Religion and Spirituality 5, no. 3 (2013). 
feel good and act well. If believing in and ritually interacting with the disembodied (or otherwise ontologically confused) intentional forces postulated by one's ingroup did not have some survival value, the cognitive and coalitional biases that engender such behaviors would not have been naturally selected and socially transmitted. Even if it was not always good for particular individuals in earlier ancestral environments, especially the victims of sexism, racism, and classism, religion (in my sense of the term) was good for the survival of the species. As we have seen in earlier chapters, archaeologists and anthropologists have argued that the placebo effects of ritual healing practices, as well as the anxiolytic effects of believing the same thing and behaving in the same way as in-group members, most likely did promote health in some early ancestral contexts. And so it should not be that surprising that such stressreducing and prosociality-producing traits could still be health-enhancing for some people, or that disaffiliation from religion in some contexts could have health-injuring effects. ${ }^{8}$

Third, much of the research on religion shaped by "positive" psychology suffers from severe methodological problems. For example, many of these studies fail to account for the well-documented "positivity bias" of religious people, who tend to over-report their sense of life satisfaction, ${ }^{9}$ as well as their actual church attendance - especially in the U.s. where the vast majority of such studies appear. ${ }^{10}$ Moreover, research on the alleged health benefits of religion in contemporary societies has been heavily skewed by its focus on believers, and relative lack of attention to non-believers. Although research on atheists has been "arrantly absent" for decades, the study of the non-religious (or irreligious) has been growing dramatically in recent years. ${ }^{11}$ As we will see in more detail below, the proportion of atheists in the population has been increasing for quite some time, a trend that is likely to continue. This growth has led to increased attention from psychologists, sociologists, and other social scientists interested in the role of (non)religion in human life. ${ }^{12}$

8 Brooks, “Don't Stop Believing: Rituals Improve Performance by Decreasing Anxiety," Organizational Behavior \& Human Decision Processes 137 (2016); Fenelon and Danielsen, "Leaving My Religion: Understanding the Relationship between Religious Disaffiliation, Health, and Well-Being," Social Science Research 57 (2016).

$9 \quad$ Headey et al., "Does Religion Make You Healthier and Longer Lived? Evidence for Germany," Social Indicators Research 119, no. 3 (2014).

10 Brenner, "Exceptional Behavior or Exceptional Identity?" Public Opinion Quarterly 75, no. 1 (2011).

11 Brewster et al., "Arrantly Absent: Atheism in Psychological Science from 2001 to 2012," The Counseling Psychologist 42, no. 5 (2014).

12 See, e.g., Bullivant and Lee, "Interdisciplinary Studies of Non-Religion and Secularity: The State of the Union," Journal of Contemporary Religion 27, no. 1 (2012); Zuckerman, Living 
As we might expect from our review of the research on the bio-cultural study of religion in earlier chapters, the extent to which shared imaginative engagement with axiologically relevant supernatural agents is correlated with well-being varies across individuals and contexts. ${ }^{13}$ This brings us to our fourth point. Many of the studies of the alleged health benefits of religion fail to attend to personality or other individual-level variables that are mediating the relevant effects. For example, recent psychological experiments following up such studies have found that health or well-being are mediated by factors like low personal locus of control, high levels of mentalizing, positive emotions, sense of community, intrinsic epistemological worldview commitment, or other health protective attitudes or behaviors, none of which are necessarily or even indirectly related to "religion." ${ }^{14}$ Moreover, recent critiques of research on the relationship between religion and well-being have demonstrated that the failure to utilize multivariate and multiple regression analyses in many of the studies in this field has led some researchers to miss the fact that they are not measuring religiosity but other individual factors like virtue, agreeableness, conscientiousness, or confidence. ${ }^{15}$

the Secular Life: New Answers to Old Questions (New York: Penguin Press, 2014), Bullivant and Ruse, eds., The Oxford Handbook of Atheism (Oxford, 2013), Zuckerman et al., The Nonreligious: Understanding Secular People and Societies, (New York: Oxford University Press, 2016), and Cipriani and Garelli, Sociology of Atheism (Leiden: Brill, 2016).

13 See, e.g., Yoon et al., "Religiousness, Spirituality, and Eudaimonic and Hedonic WellBeing," Counselling Psychology Quarterly 28, no. 2 (2015); Shiah et al., "Religion and Subjective Well-Being: Western and Eastern Religious Groups Achieved Subjective Well-Being in Different Ways," Journal of Religion and Health 55, no. 4 (2016).

14 See, e.g., Osborne et al., "Examining the Indirect Effects of Religious Orientations on Wellbeing through Personal Locus of Control," European Journal of Social Psychology 46, no. 4 (2016), van Cappellen et al., "Religion and Well-Being: The Mediating Role of Positive Emotions," Journal of Happiness Studies 17, no. 2 (2016), van Cappellen et al., "Religiosity and Prosocial Behavior Among Churchgoers: Exploring Underlying Mechanisms," The International Journal for the Psychology of Religion 26, no. 1 (2016), Routledge et al., "Further Exploring the Link Between Religion and Existential Health: The Effects of Religiosity and Trait Differences in Mentalizing on Indicators of Meaning in Life," Journal of Religion and Health 56, no. 2 (2017), Steffen et al., "What Mediates the Relationship Between Religious Service Attendance and Aspects of Well-Being?” Journal of Religion and Health 56, no. 1 (2017), Speed, "Unbelievable?! Theistic/Epistemological Viewpoint Affects Religion - Health Relationship," Journal of Religion and Health 56, no. 1 (2017), and Ng and Fisher, "Protestant Spirituality and Well-Being of People in Hong Kong: The Mediating Role of Sense of Community," Applied Research in Quality of Life 11, no. 4 (2016).

15 This critique is spelled out in detail in Schuurmans-Stekhoven, "Is It God or Just the Data That Moves in Mysterious Ways? How Well-Being Research May Be Mistaking Faith for Virtue," Social Indicators Research 100, no. 2 (2010), Galen and Kloet, "Mental Well-Being in the Religious and the Non-Religious: Evidence for a Curvilinear Relationship," Mental 
Fifth, a similar mistake in many studies of the relationship between religion and health is the failure to account for group-level variables that are mediating (or causing) feelings of well-being or prosocial behaviors. Is "religion" really the cause - or the only cause - of prosociality? A recent study involving experimental manipulation (priming) concluded that "religion is not fundamental to moral priming, and it is likely the perceived benefits of being in a group that enhances prosociality."16 Another critical review of recent research in this field found that "this literature has often conflated belief in God with group involvement and failed to control for demographic and social network effects."17 Once these controls are in place, multiple regression analyses indicate that the benefits of prosociality are more related to group membership in general rather than specifically religious content. In other words, it seems that it is social affiliation, or a sense of "belonging" in general, rather than religious affiliation, or belief in particular, that engenders feeling good and acting well. ${ }^{18}$

This is supported by psychological research showing that there is no evidence of a connection between the content of religious belief and variables like health, well-being, life satisfaction, etc. Categories of belief (atheist, agnostic, theist, etc.) are generally unrelated to reported global health, which suggests that "belief in God is not inherently linked to better health ... [and that] nonbelief in God is not associated with any type of health penalty." ${ }^{19}$ A similar study demonstrated that generally speaking "Christians were no more or less healthy than the Religiously Unaffiliated." ${ }^{20}$ Another survey analysis found that atheists do not differ from Christians or Buddhists on measures such as well-being, sociality, joviality, emotional stability, happiness, compassion, and

Health, Religion \& Culture 14, no. 7 (2011), and Schuurmans-Stekhoven, "Spirit or Fleeting Apparition? Why Spirituality's Link with Social Support Might Be Incrementally Invalid," Journal of Religion and Health, 56, no. 4 (2017).

16 Thomson, "Priming Social Affiliation Promotes Morality - Regardless of Religion," Personality and Individual Differences 75 (2015): 195-200. Emphases added.

17 Galen et al., "Nonreligious Group Factors Versus Religious Belief in the Prediction of Prosociality," Social Indicators Research 122, no. 2 (2015): 411.

18 See, e.g., ten Kate et al., "The Effect of Religiosity on Life Satisfaction in a Secularized Context: Assessing the Relevance of Believing and Belonging," Review of Religious Research 59, no. 2 (2017).

19 Speed and Fowler, "What's God Got to Do with It? How Religiosity Predicts Atheists' Health," Journal of Religion and Health 55, no. 1 (2016): 305.

20 Speed and Fowler, "Good for All? Hardly! Attending Church Does Not Benefit Religiously Unaffiliated," Journal of Religion and Health 56, no. 3 (2017). 
empathic concern. ${ }^{21}$ It may well be that level of confidence about beliefs (or the extent to which one values one's beliefs) plays a role in promoting wellbeing. When comparing those with confident disbelief in God to those with confident belief in God, however, studies show no difference in well-being. ${ }^{22}$

A sixth response to this question is to point out all of the ways that religion is "bad for us." Throughout this book, I have been exploring the unpleasant consequences of engaging in religious sects, especially the ways in which it can directly promote superstitious interpretations of nature and amplify segregative inscriptions of society, which exacerbate the global (and local) challenges we all face today. It is important not to ignore the explictly negative effects that religion can have on human health and well-being. For example, recent converts may initially "feel good" participating in new religious movements, but this bump in some aspects of their mental health is correlated with reduced autonomy and submissiveness to "unjustified and meaningless requests," lowering optimal development and well-being. ${ }^{23}$

The negative health effects of religion are particularly obvious in relation to anxiogenic religious beliefs such as those related to demons, hell, or other forms of supernatural malevolence. ${ }^{24}$ However, the problem does not seem to be limited to fundamentalist individuals who interpret the holy texts of their in-groups literally. A country level analysis of the World Values Survey (including 59 countries) found that life satisfaction was negatively predicted by religious belief. That is to say, "more religious countries showed lower mean levels of life satisfaction than less religious countries." ${ }^{25}$ Moreover, some recent studies suggest that in comparison to the non-religious, religious people have either the same or worse health outcomes or levels of well-being, especially when statistical analyses are in place to control for other variables. ${ }^{26}$

21 Caldwell-Harris et al., "Exploring the Atheist Personality: Well-Being, Awe, and Magical Thinking in Atheists, Buddhists, and Christians," Mental Health, Religion \& Culture 14, no. 7 (2011).

22 Galen and Kloet, "Mental Well-Being in the Religious and the Non-Religious."

23 Buxant and Saroglou, "Feeling Good, but Lacking Autonomy: Closed-Mindedness on Social and Moral Issues in New Religious Movements," Journal of Religion and Health 47, no. 1 (2008): 27 .

24 Shariff and Aknin, "The Emotional Toll of Hell: Cross-National and Experimental Evidence for the Negative Well-Being Effects of Hell Beliefs," PLoS ONE 9, no. 1 (2014).

25 Plouffe and Tremblay, "The Relationship between Income and Life Satisfaction: Does Religiosity Play a Role?" Personality and Individual Differences 109 (2017): 70.

26 Hayward et al., "Externalizing Religious Health Beliefs and Health and Well-Being Outcomes," Journal of Behavioral Medicine 39, no. 5 (2016); Hayward et al., "Health and WellBeing Among the Non-Religious: Atheists, Agnostics, and No Preference Compared with 
Finally, these rather obvious and direct negative effects of religion are in some ways less difficult to deal with than the indirect consequences of the surreptitious reciprocal reinforcement of theogonic mechanisms we have been exploring throughout this book. Even in those cases where shared imaginative ritual engagement with supernatural agents has some health benefits for some individuals in some contexts, it is still bad for the rest of us. The mutual amplification of theistic credulity and theistic conformity biases is covertly at work even in relatively peaceful communities of relatively stable religious individuals. Under psychologically, sociologically, or ecologically stressful conditions, however, these evolved biases toward explaining the world and organizing the social field by appealing to the supernatural agents of one's own religious ingroup can all too easily promote extreme ideologies and intergroup violence. We need to get better at contesting these biases. Can naturalist reasoning and secularist socializing help?

\section{Safe Sects and Analytic Thought}

In the next three sub-sections, I outline some of the more recent evidence for the claim that atheism - the attempt to make sense of nature and act sensibly in society without appealing to supernatural agents and authorities - can help us practice safe $(r)$ sects. One of the main reasons for hope, as we will see in more detail below, is that although setting these theolytic mechanisms in motion often requires a great deal of intellectual and social investment, they reciprocally reinforce one another once they get going. Promoting anthropomorphic prudery and sociographic promiscuity will not automatically solve all of our problems, but it can contribute to the dissolution of pernicious theistic biases that complicate human life by triggering cognitive mistakes and coalitional conflicts. It may also loosen the hold that other biases, like sexism, classism, and racism have on human minds and cultures.

Many people will intitially be quite suspicious of these claims. This is not surprising since one of the most significant and well-documented consequences of thestic bias is a strong prejudice against non-theists. ${ }^{27}$ There are

Religious Group Members," Journal of Religion and Health 55, no. 3 (2016); Hwang, "Atheism, Health, and Well-Being," in The Oxford Handbook of Atheism ed. Bullivant and Ruse (Oxford, 2013).

27 Andersson, "Atheism and How It Is Perceived: Manipulation of, Bias against, and Ways to Reduce the Bias," Nordic Psychology, 68, no. 3 (2016); Gervais et al., "Global Evidence of Extreme Intuitive Moral Prejudice against Atheists" Nature Human Behavior 1 (2017): 1-5. 
complex reasons for this prejudice, which varies among individuals and across contexts. ${ }^{28}$ In light of the role that theogonic mechanisms have played in promoting cooperation, coordination, and competition in human coalitions, we can understand why some people might not trust non-believers to behave. If atheists don't believe that punitive gods are watching them, how can we be sure they will follow the rules? As we will see in the next section, this anti-atheism is really biased; that is, non-believers in general are (at least) as prosocial as believers. Like all unfair group biases, however, prejudice against nonbelievers can have a negative effect on the physical and psychological well-being of the target group, ${ }^{29}$ which might help to explain why atheism has not been growing even more rapidly worldwide. Happily, a growing body of research is beginning to shed light on the conditions under which - and the mechanisms by which this anti-atheist prejudice can be dissolved. ${ }^{30}$

This section focuses on the strong correlation (and plausible causal link) between analytic thought and atheism. Non-believers tend to be more critically reflective, and are over-represented in the academy in general and among elite scientists in particular. ${ }^{31}$ However, it is important to emphasize that not all atheists are created equally (or, better, not all followed the same developmental route into atheism). As research on atheists continues to grow, scholars

28 Hughes et al., “Tolerating the 'Doubting Thomas': How Centrality of Religious Beliefs vs. Practices Influences Prejudice against atheists," Frontiers in Psychology 6 (2015). Cragun et al., "On the Receiving End: Discrimination toward the Non-Religious in the United States," Journal of Contemporary Religion 27, no. 1 (2012); Cragun et al., "Perceived Marginalization, Educational Contexts, and (Non)Religious Educational Experience," Journal of College and Character 17, no. 4 (2016); Edgell et al., "From Existential to Social Understandings of Risk: Examining Gender Differences in Nonreligion," Social Currents 4, no. 6 (2017); Clobert et al., "East Asian Religious Tolerance versus Western Monotheist Prejudice: The Role of (In)tolerance of Contradiction," Group Processes \& Intergroup Relations 20, no. 2 (2017).

29 Doane and Elliott, "Perceptions of Discrimination Among Atheists: Consequences for Atheist Identification, Psychological and Physical Well-Being," Psychology of Religion and Spirituality 7, no. 2 (2015); Weber et al., "Psychological Distress Among Religious Nonbelievers: A Systematic Review," Journal of Religion and Health 51, no. 1 (2012).

$30 \quad$ See, e.g., Labouff and Ledoux, "Imagining Atheists: Reducing Fundamental Distrust in Atheist Intergroup Attitudes," Psychology of Religion and Spirituality 8, no. 4 (2016); Gervais, "Finding the Faithless: Perceived Atheist Prevalence Reduces Anti-Atheist Prejudice," Personality and Social Psychology Bulletin 37, no. 4 (2011); Simpson and Rios, "The Moral Contents of Anti-Atheist Prejudice (and Why Atheists Should Care about It)," European Journal of Social Psychology 47, no. 1 (2017).

31 Caldwell-Harris, "Understanding Atheism/Non-Belief as an Expected IndividualDifferences Variable," Religion, Brain \& Behavior 2, no. 1 (2012). 
are identifying a wide variety of pathways to - and types of - disbelief and disaffiliation. ${ }^{32}$ Any particular individual's atheism will be the result of some complex combination of cognitive, motivational, social, and other factors. ${ }^{33}$ Within this broad field of "atheodiversity," my special interest in what follows is in the connection between non-belief in supernatural agents (anthropomorphic prudery) and individual level variables like analytic cognitive style, education, and intelligence.

Throughout this book, and especially in Chapter 1, we have pointed to a large number of empirical studies demonstrating that religious individuals are more likely to make errors in reasoning related to detecting randomness and purposiveness (compared to non-religious individuals). We can turn this around and say it the other way: atheists and skeptics are better in general at contesting their teleological biases and other hyper-active anthropomorphizing tendencies. In some cases, of course, this may not be a conscious, effortful contestation; sometimes personality variables or contextual conditions make it relatively easy for the non-religious to abstain from religious sects. For whatever complex set of reasons, research consistently shows a strong correlation between low levels of religiosity and high levels of resistance to the biases that promote anthropomorphic promiscuity.

For example, the results of several psychological studies indicate that skeptics are less prone to illusory agency detection than paranormal believers and that non-believers are less likely to categorize ambiguous stimuli as facelike. ${ }^{34}$ Other experiments have shown that analytically-thinking skeptics are better able to resist the biases that predispose humans toward religious and paranormal beliefs with supernatural content, which "is the only thing that joins religious and paranormal beliefs and ... the only thing that distinguishes

32 See, e.g., Silver et al., "The Six Types of Nonbelief: A Qualitative and Quantitative Study of Type and Narrative," Mental Health, Religion \& Culture 17, no. 10 (2014), Schnell, "Dimensions of Secularity (DoS): An Open Inventory to Measure Facets of Secular," The International Journal for the Psychology of Religion 25, no. 4 (2015), and Stolz, "Institutional, Alternative, Distanced, and Secular," Nordic Journal of Religion and Society 30, no. 1 (2017).

See, e.g., Norenzayan, "Theodiversity," Annual Review of Psychology 67 (2016); Kalkman, "Three Cognitive Routes to Atheism: A Dual-Process Account," Religion 44, no. 1 (2014); Stewart, "The True (Non)believer? Atheists and the Atheistic in the United States," in Sociology of Atheism (Leiden: Brill Academic, 2016); Norenzayan and Gervais, "The Origins of Religious Disbelief", and Blanes and Oustinova-Stjepanovic, eds., Being Godless: Ethnographies of Atheism and Non-Religion (New York: Berghahn Books, 2017).

34 See, e.g., van Elk, "Paranormal Believers Are More Prone to Illusory Agency Detection than Skeptics," Consciousness and Cognition 22, no. 3 (2013), and van Elk, "Perceptual Biases in Relation to Paranormal and Conspiracy Beliefs," PLoS ONE 10, no. 6 (2015). 
religiosity from non-religiosity."35 Another experimental study comparing the relative tendencies toward false detection of anthropomorphic figures among religious believers and non-believers suggested that all humans may "be biased to perceive human characteristics where none exist, but religious and paranormal believers perceive them even more than do others." ${ }^{36}$

The point here is not that non-believers are completely free of such implicit biases, but that in general they are better able to resist them when trying to explain ambiguous phenomenon. They may exhibit such biases when under time pressure but, as the authors of one study on teleological reasoning put it, non-believers are able to inhibit such intuitions and "abandon them as guiding principles in reflective reasoning." ${ }^{37}$ The authors of one experiment that found an association between low levels of religiosity and low levels of anthropomorphism concluded that the latter enables atheists "to interpret the non-animal world in terms of non-agentic forces and thus frees them from potential theistic conceptualization in their dealings with the world."38 All of this makes sense in light of neuroscientific insights into the biological and cognitive underpinnings of religious misattributions. Such research suggests that supernatural beliefs and experiences are the result of "reduced error monitoring" in both interoceptive and exteroceptive inference processes, upon which religious prayer and hallucinations respectively rely. ${ }^{39}$

This mental advantage that atheists have over theists extends to intellectual reasoning in general, and even to the capacity for identifying valid logical deductions in particular. One study that assessed performance on logical (syllogistic) reasoning problems found that skeptics made fewer errors than believers. This evidence suggests that religious skeptics, compared to believers, are

35 Lindeman et al., "Skepticism: Genuine Unbelief or Implicit Beliefs in the Supernatural?" Consciousness and Cognition 42 (2016): 225.

36 Riekki et al., "Paranormal and Religious Believers Are More Prone to Illusory Face Perception than Skeptics and Non-believers," Applied Cognitive Psychology 27, no. 2 (2013).

37 Järnefelt et al., "The Divided Mind of a Disbeliever: Intuitive Beliefs about Nature as Purposefully Created among Different Groups of Non-Religious Adults," Cognition 140 (2015), 83; see also Heywood and Bering, "Meant to Be': How Religious Beliefs and Cultural Religiosity Affect the Implicit Bias to Think Teleologically," Religion, Brain \& Behavior 4, no. 3 (2014).

$38 \quad$ Talbot and Wastell, "Corrected by Reflection: The De-Anthropomorphized Mindset of Atheism," Journal for the Cognitive Science of Religion 3, no. 2 (2017): 121.

39 van Elk and Aleman, "Brain Mechanisms in Religion and Spirituality: An Integrative Predictive Processing Framework," Neuroscience and Biobehavioral Reviews 73 (2017). See also Zhong et al., "Biological and Cognitive Underpinnings of Religious Fundamentalism," Neuropsychologia 100 (2017). 
both "more reflective and effective in logical reasoning tasks." ${ }^{\text {"0 }} \mathrm{A}$ recent metaanalysis reported that the vast majority of relevant research papers on this topic discovered a correlation between analytic thinking and religious disbelief. In the same article, the authors reported on four new empirical analyses that provided further confirmation of the impact of "the mere willingness to think analytically" on religious disbelief. All of this evidence suggests that statistically speaking "atheists and agnostics are more reflective than religious believers." ${ }^{41}$

But is this individual level difference between theists and atheists due primarily to cognitive style or cognitive ability (or both)? Several of the studies we have already cited in this section emphasize the role that the former plays in predicting religious (dis)belief.42 There is also evidence that cognitive style has an impact on belief in God not only in the short term but over time as well. For example, one study showed that participants with a more intuitive rather than reflective or analytic - cognitive style were more likely to report a stronger belief in God since childhood, regardless of familial religiosity during formative years. ${ }^{43}$ Other studies have explored the differentiation between these variables. For example, one recent survey analysis suggested that religiosity is predicted by (lack of) analytic cognitive style, while social conservatism is predicted by (lower) cognitive ability. ${ }^{44}$ Another survey analysis, explicitly designed to measure all three variables (religiosity, cognitive style and cognitive ability), found that "those with higher cognitive ability are less likely to accept religious doctrine or engage in religious behaviors and those with lower ability are more likely to accept religious doctrine and exhibit higher levels of fundamentalism." 45

40 Pennycook et al., "Belief Bias during Reasoning among Religious Believers and Skeptics," Psychonomic Bulletin \& Review 20, no. 4 (2013): 806. See also the classic study by Klaczynski and Gordon, "Self-Serving Influences on Adolescents' Evaluations of Belief-Relevant Evidence," Journal of Experimental Child Psychology 62, no. 3 (1997), which showed how the reasoning of religious adolescents was systematically biased toward protecting and promoting pre-existing religious beliefs.

41 Pennycook et al., "Atheists and Agnostics Are More Reflective than Religious Believers: Four Empirical Studies and a Meta-Analysis," PLoS ONE 11, no. 4 (2016): 1.

42 For other examples, see Pennycook et al., "Analytic Cognitive Style Predicts Religious and Paranormal Belief," Cognition 123, no. 3 (2012), and Pennycook, "Evidence That Analytic Cognitive Style Influences Religious Belief: Comment on Razmyar and Reeve," Intelligence 43 (2014).

43 Shenhav et al., "Divine Intuition: Cognitive Style Influences Belief in God," Journal of Experimental Psychology: General 141, no. 3 (2013).

44 Saribay and Yilmaz, "Analytic Cognitive Style and Cognitive Ability Differentially Predict Religiosity and Social Conservatism," Personality and Individual Differences 114 (2017).

45 Razmyar and Reeve, "Individual Differences in Religiosity as a Function of Cognitive Ability and Cognitive Style," Intelligence 41, no. 5 (2013): 667. 
A high level of education is another variable often associated with low levels of religiosity. Although this connection is slightly more contentious, multiple studies have found that education levels are a strong predictor of both religious disbelief and religious disaffiliation. ${ }^{46}$ It makes sense that being encouraged to think critically while learning about scientific explanations and humanistic interpretations would have a generally enervating effect on theogonic mechanisms. Statistical analyses suggest that, at the national level, student performance in science and mathematics is lower in countries with high levels of religiosity ${ }^{47}$ Not surprisingly, analytic thinking in an educational context predicts increased acceptance of evolution, which is generally considered a threat to religion. ${ }^{48}$ All of this evidence suggests that "the conflicts between science and religion are not only the result of surface-level moral and epistemological conflicts, but are underpinned by divergent cognitive processes that promote religious belief and undermine scientific understanding."49

The negative relationship between religiosity and intelligence per se is even more well-documented and empirically validated. While intelligence has an impact on educational attainment, the latter is not necessarily what mediates the negative effect of the former on religious belief and behavior. ${ }^{50} \mathrm{~A}$ recent meta-analysis of 63 studies documented the overwhelming consensus about the significant correlation between high intelligence and low religiosity across populations..$^{51}$ One study involving a sample of 137 nations found that the average intelligence of a population predicts the percentage of people who do not believe in God. ${ }^{52}$ Another set of survey analyses found that the negative

46 See, e.g., Hungerman, "The Effect of Education on Religion: Evidence from Compulsory Schooling Laws," Journal Of Economic Behavior \& Organization 104 (2014); Lewis, "Education, Irreligion, and Non-Religion: Evidence from Select Anglophone Census Data," Journal of Contemporary Religion 30, no. 2 (2015).

47 Stoet and Geary, "Students in Countries with Higher Levels of Religiosity Perform Lower in Science and Mathematics," Intelligence 62 (2017).

48 Gervais, "Override the Controversy: Analytic Thinking Predicts Endorsement of Evolution," Cognition 142 (2015).

49 McPhetres and Nguyen, "Using Findings from the Cognitive Science of Religion to Understand Current Conflicts between Religious and Scientific Ideologies," Religion, Brain \& Behavior 7 (2017): 8.

5o Ganzach et al., "On Intelligence Education and Religious Beliefs," Intelligence 41, no. 2 (2013).

51 Zuckerman et al., "The Relation Between Intelligence and Religiosity: A Meta-Analysis and Some Proposed Explanations," Personality and Social Psychology Review 17, no. 4 (2013).

52 Lynn et al., "Average Intelligence Predicts Atheism Rates across 137 Nations," Intelligence 37 , no. 1 (2009). 
intelligence-religiosity link seems to be more robust across people than it is across countries, which highlights the importance of considering the role of other variables (such as education and quality of life) in moderating the link. ${ }^{53}$ Is the negative correlation between intelligence and religiosity primarily a result of religious belief or religious affiliation? One study found that, at least in the case of older adults, religious belief seems to be the driver of this negative association. ${ }^{54}$

Research designs involving longitudinal within-families and cross-sectional analysis of changes in religious belief provide some warrant for inferring causality: over time the "more intelligent" tend to become "less religious." 55 Psychological experiments involving manipulation (priming), and guided by dual-process theories of cognition, also provide evidence of a causal relationship: triggering analytic processing increases religious disbelief in the laboratory. ${ }^{56}$ Although there are many factors at play in the promotion of supernatural agent beliefs, in light of all the evidence discussed so far (here and in previous chapters) it makes sense to claim that they can be demoted by the activation of analytic thinking. Anticipating our discussion of the mutual intensification of theolytic mechanisms below, it is important to note that experimental studies demonstrate not only that analytic thinking promotes religious disbelief, but also that it reduces prejudice. ${ }^{57}$

As we have seen, both genetic and environmental factors contribute to individual levels of (non)religiosity. The same applies to analytic thinking style and intelligence. In fact, the heritability of these traits helps to explain the

53 Webster and Duffy, "Losing Faith in the Intelligence-Religiosity Link: New Evidence for a Decline Effect, Spatial Dependence, and Mediation by Education and Life Quality," Intelligence 55 (2016).

54 Ritchie et al., "Religiosity Is Negatively Associated with Later-Life Intelligence, but Not with Age-Related Cognitive Decline," Intelligence 46 (2014).

55 Ganzach and Gotlibovski, "Intelligence and Religiosity: Within Families and over Time," Intelligence 41, no. 5 (2013): 551 .

56 Gervais and Norenzayan, "Analytic Thinking Promotes Religious Disbelief," Science 336, no. 6080 (2012). However, it is important to note that these results could not be replicated by Sanchez et al., "Direct Replication of Gervais \& Norenzayan (2012): No Evidence That Analytic Thinking Decreases Religious Belief" PLoS ONE 12, no. 2 (2017). Another study found that implicit religiosity was not reduced when analytic thinking was primed:Yonker et al., "Primed Analytic Thought and Religiosity: The Importance of Individual Characteristics," Psychology of Religion and Spirituality 8, no. 4 (2016), suggesting the need to take individual characteristics into account in such priming studies.

57 Yilmaz et al., "Analytic Thinking, Religion, and Prejudice: An Experimental Test of the Dual-Process Model of Mind," The International Journal for the Psychology of Religion 26, no. 4 (2016). 
negative correlation we have been discussing. In changing ecologies, problem solving abilities would be associated with the capacity and willingness to resist biases that evolved in earlier ecological contexts. This has led some scholars to conclude that intelligence was naturally selected as individuals who were "intellectuallly curious and thus open to non-instinctive possibilities" resisted religious (and other) biases and gained the survival advantage.$^{58}$ For most people, throughout most of human history, the bio-cultural pressures exerted by theistic conformity biases have usually overpowered intellectual resistance to theistic credulity biases.

Today human fertility is positively correlated with religiosity and negatively correlated with intelligence. Unless naturalism and secularization forces continue to gain ground and override projections based primarily on fertility rates, this means that as the world becomes more religious "the genes promoting religiosity will spread and the genes for intelligence will diminish." To face global challenges related to extreme climate change, excessive consumer capitalism, and escalating cultural conflict, we need scientific and philosophical reasoning that can resist superstitious appeals to hidden supernatural agents. That kind of analytic thinking "requires genes for high intelligence and is facilitated by genes for low religosity." ${ }^{59}$ We will return below to the prospects for an adaptive atheism.

But don't lots of intelligent and well-educated people believe in God (not to mention angels, demons, saints, genies, devas, and other supernatural agents)? Indeed they do. For thousands of years the majority of the intellectual (and priestly) elite in large-scale societies have participated in and promoted unsafe sects, engendering all sorts of superstitious supernatural conceptions. Although a few ancient and early modern philosophers and naturalists explicitly resisted the temptations of anthropomorphic promiscuity, atheism did not become widespread until after the natural (and later evolutionary) origins of religion were discovered. ${ }^{60}$

Many smart people today still argue for the existence of god(s) and participate in the rituals of their religious in-groups. As we noted in Chapter 5,

58 Dutton and van der Linden, "Why Is Intelligence Negatively Associated with Religiousness?" Evolutionary Psychological Science 3, no. 4 (2017): 401; See also Kandler and Riemann, "Genetic and Environmental Sources of Individual Religiousness: The Roles of Individual Personality Traits and Perceived Environmental Religiousness," Behavior Genetics 43, no. 4 (2013).

59 Ellis et al., "The Future of Secularism: A Biologically Informed Theory Supplemented with Cross-Cultural Evidence," Evolutionary Psychological Science 3, no. 3 (2017): 238.

60 Collier, "The Natural Foundations of Religion," Philosophical Psychology 27, no. 5 (2014). 
religiously affiliated scholars often make the same sort of errors in reasoning as their less-educated peers. ${ }^{61}$ The intellectual habits and methodological practices fostered by science and (non-religious) philosophy can help entrain resistance to theistic credulity biases, but the latter continue to surreptitiously shape the abductive inferences of scholars engaged in religious sects. This is one example of the way in which even intellectuals can be powerfully (and covertly) influenced by evolved biases like motivated reasoning (or high levels of schizotypy). ${ }^{62}$

Even if one grants that analytical reasoning and atheism are correlated and causally connected, there might still be reasons not to promote either. Nonbelievers who contest their evolved intuitions, it might be argued, are generally more angry and less happy than believers, and so we ought to let sleeping theist biases lie. Here too it turns out that such claims are not warranted by the data. In fact, these anti-atheist prejudices are explicilty contradicted by the empirical evidence. The myth of the "angry atheist" is precisely that - a myth. A recent set of studies found that neither belief nor non-belief in God is correlated with measures of trait anger. ${ }^{63}$ Perhaps even more surprisingly to many, an analysis of World Values Survey data found that belief in scientific-technological progress (a trait associated with anthropomorphic prudery) is a stronger predictor of life-satisfaction than religious belief in 69 out of 72 countries. ${ }^{64}$

The fact that atheists in general have stronger analytic and higher intellectual capacities does not mean that they will tend to be cold and emotionless. In fact, a set of studies on the relation between atheism, religion, and emotion found that individuals who identify themselves as religious "reported greater logical difficulty with respect to differentiating their emotions compared to atheists." Or, to put it positively: "atheists reported greater general facility with

61 Tobia, "Does Religious Belief Infect Philosophical Analysis?" See also Draper and Nichols, "Diagnosing Bias in Philosophy of Religion."

62 MacPherson and Kelly, "Creativity and Positive Schizotypy Influence the Conflict between Science and Religion," Personality and Individual Differences 50, no. 4 (2011).

63 Meier et al., "The Myth of the Angry Atheist," The Journal of Psychology 149, no. 3 (2015). However, it is important to acknowledge that some atheists can be as "dogmatic" about their disbelief as theists are about their belief. Fundamentalist tendencies in either direction can predispose individuals toward out-group prejudice. See Kossowska et al., "Many Faces of Dogmatism: Prejudice as a Way of Protecting Certainty against Value Violators among Dogmatic Believers and Atheists," British Journal of Psychology 108, no. 1 (2017), and Brandt and van Tongeren, "People Both High and Low on Religious Fundamentalism Are Prejudiced Toward Dissimilar Groups," Journal of Personality and Social Psychology (2015).

64 Stavrova et al., "Belief in Scientific-Technological Progress and Life Satisfaction: The Role of Personal Control," Personality and Individual Differences 96 (2016). 
respect to focusing on, identifying, and describing their own emotions." ${ }^{25}$ Many atheists also have intense experiences of joy, awe, and self-transcendence that are neither explicitly nor implicitly "religious." ${ }^{66}$ Like believers, there are many sub-groups and individual differences between non-believers, but recent empirical research on these variables suggests that both religious and nonreligious people can have strong empathizing tendencies. ${ }^{67}$ Atheists may on average be smarter, more reflective, better educated, and more in control of their emotional states - but they are less moral than religious people. Right?

\section{Safe Sects and Altruistic Behavior}

Here too it is important to begin by confronting the anti-atheist prejudice that will lead many readers to quickly dismiss the idea that sociographic promiscuity can promote the construction and maintenance of good societies. Social psychological experiments have shown that people will tend to give more negative moral appraisals of atheists (compared to Christian theists) even when they performed exactly the same moral or immoral actions. ${ }^{68}$ This stereotype against non-believers seems to be mediated by a lack of moral trust. People appear to expect atheists to behave badly, and somewhat automatically set up moral boundaries to protect themselves. ${ }^{69}$ However, this implicit prejudice is reduced when non-believers are perceived to be prevalent in a society. In fact, experimentally induced reminders of atheist prevalence appear to cause a decrease in explicit distrust of atheists. ${ }^{70}$ The results of other experiments

65 Burris and Petrican, "Hearts Strangely Warmed (and Cooled): Emotional Experience in Religious and Atheistic Individuals," International Journal for the Psychology of Religion 21, no. 3 (2011): 193 .

66 Coleman et al., "Focusing on Horizontal Transcendence: Much More than a 'Non-Belief," Essays in the Philosophy of Humanism 21, no. 2 (2014).

67 Lindeman and Lipsanen, "Diverse Cognitive Profiles of Religious Believers and Nonbelievers." The International Journal for the Psychology of Religion 26, no. 3 (2016).

68 Wright and Nichols, "The Social Cost of Atheism: How Perceived Religiosity Influences Moral Appraisal," Journal of Cognition and Culture 14, no. 1-2 (2014).

69 Gervais et al., "Do You Believe in Atheists? Distrust Is Central to Anti-Atheist Prejudice," Journal of Personality and Social Psychology 101, no. 6 (2011); Gervais and Norenzayan, "Religion and the Origins of Anti-Atheist Prejudice," in Intolerance and Conflict: A Scientific and Conceptual Investigation, ed. Clarke et al. (Oxford, 2013); Edgell et al., "Atheists and Other Cultural Outsiders: Moral Boundaries and the Non-religious in the United States," Social Forces 95, no. 2 (2017).

70 Gervais, "Finding the Faithless: Perceived Atheist Prevalence Reduces Anti-Atheist Prejudice," Personality and Social Psychology Bulletin 37, no. 4 (2011). 
indicate that priming thoughts about secular authority or government can have a similar effect. ${ }^{71}$

As the percentage of non-religious people in the population continues to grow, so does the recognition that we can be good without God. ${ }^{72}$ But don't we need religion to make us moral? It is not difficult to understand why this myth is so widespread. For most of the history of the human species, moral norms have been justified by appeals to supernatural agents and authorities. As we have seen in earlier chapters, over time and in a variety of places bigger gods and bigger societies co-evolved; large-scale cooperation appears to have been enhanced by shared imaginative engagement with larger (smarter, stronger, and more punitive) supernatural agents. ${ }^{73}$ The priestly and intellectual elites of the west Asian monotheistic religions that emerged in the wake of the axial age, and helped to fuel the growth of massive empires into the modern period, eventually postulated the existence of an infinitely powerful and eternally punitive God.

However, we have good reasons to believe that none of this implies that religions are necessary for morality. From the evolutionary history of social insects it is clear that mechanisms contributing to group social control and to the development of altruistic behavior in individual organisms have been operative for millions of years. Long before the emergence of Homo sapiens, eusocial animals - including many other primate species - were coordinating and competing with other groups. ${ }^{74}$ Altruistic care of genetic kin, as well as direct and indirect reciprocity with cooperating kith, were among the moral behaviors that helped individual members of such species survive and protect their offspring long enough to reproduce..$^{75}$ Another important part of this

71 Gervais and Norenzayan, “Reminders of Secular Authority Reduce Believers' Distrust of Atheists," Psychological Science 23, no. 5 (2012).

72 Epstein, Good Without God: What a Billion Nonreligious People Do Believe (William Morrow Paperbacks, 2010); Blackford and Schuklenk, 50 Great Myths About Atheism (Hoboken: Wiley-Blackwell, 2013).

73 See also Norenzayan and Shariff, "The Origin and Evolution of Religious Prosociality," Science 322 , no. 5898 (2008).

74 de Waal, ed., Evolved Morality: The Biology and Philosophy of Human Conscience (Leiden: Brill Academic Publishers, 2014); Boehm, Moral Origins: The Evolution of Virtue, Altruism, and Shame (New York: Basic Books, 2012); Sinnott-Armstrong and Miller, eds., Moral Psychology, The Evolution of Morality: Adaptations and Innateness, Vol. 1 (Cambridge, Mass: The MIT Press, 2007).

75 Krebs and Denton, "The Evolution of Sociality, Helping, and Morality," in The Oxford Handbook of Secularism, ed. Zuckerman and Shook (New York: Oxford University Press, 2017). 
process, as we have seen, was the natural selection of genetic tendencies that reinforced individual's willingess to punish, and reward other's punishment of, cheaters and free-loaders.

Today, however, we have significant evidence that secular societies are able to promote prosociality at least as well as religious societies. One type of evidence comes from priming studies. Experimentally induced reminders of secular moral authority have the same sort of effect on altruistic behavior as reminders of supernatural authority. One study tested the impact of implicit priming on behavior in an anonymous dictator game and found that "implicit activation of concepts related to secular moral institutions restrained selfishness as much as did religious suggestion." ${ }^{76} \mathrm{~A}$ similar study in Japan found that there was no difference between the amount of money allocated to strangers among the three priming conditions (religious, secular justic, control), with the somewhat surprising exception that theists allocated more money than atheists under the secular justice condition. ${ }^{77}$

The results of other priming experiments indicate that it is triggering thoughts about social affiliation in general - not religious affiliation in particular - that promote morality. ${ }^{78}$ In other words, the same prosociality enhancing mechanisms that operate within religious sects can also operate within more sociographically promiscuous societies. Secular institutions like relatively transparent democratic legislatures, contract-enforcing courts, and policing authorities are more recent than religious institutions, but they too can foster large-scale trust and cooperation. Both gods and governments can "function as social monitors to encourage cooperation among individuals." 79 It is not supernatural beliefs nor even participation in supernatural rituals per se that engender altruistic behaviors. It turns out that the apparent prosocial benefits of religious sects are actually the benefits of sociality itself.

$7_{6}$ Shariff and Norenzayan, "God Is Watching You: Priming God Concepts Increases Prosocial Behavior in an Anonymous Economic Game," Psychological Science 18, no. 9 (2007): 807. See also Norenzayan, “Does Religion Make People Moral?" Behaviour 151, no. 2-3 (2014): 380 , and Yilmaz and Bahçekapili, "Supernatural and Secular Monitors Promote Human Cooperation Only If They Remind of Punishment," Evolution and Human Behavior 37, no. 1 (2016).

77 Miyatake and Higuchi, "Does Religious Priming Increase the Prosocial Behaviour of a Japanese Sample in an Anonymous Economic Game?” Asian Journal of Social Psychology 20, no. 1 (2017).

78 Thomson, "Priming Social Affiliation Promotes Morality - Regardless of Religion." Personality and Religious Differences, 75 (2015).

79 Gervais and Norenzayan, "Reminders of Secular Authority Reduce Believers' Distrust of Atheists," Psychological Science 23, no. 5 (2012): 489 . 
We also have evidence from survey analyses that contradicts the idea that being religious makes people more altruistic. A broad analysis of U.S. survey data suggested that any form of voluntary association tends to make people feel better, safer, and more able to contribute to just and stable societies. It seems that membership in a secular bowling league, for example, is just as likely to boost charitable giving as affiliation within a religious organization. ${ }^{80}$ Although some earlier studies found at least a weak correlation between factors related to religiosity and prosociality, such as reported generosity and willingness to help strangers, these have more recently come under serious critique due to their lack of conceptual clarity, their confounding of factors, and the fact that they are powerfully contradicted by experiments that test actual economic and other behaviors. ${ }^{81}$ The bulk of the evidence indicates an absence of - or even a negative - correlation between religiosity and actual prosocial behavior. ${ }^{82}$

Religious people do give more to their own in-groups (e.g., churches), especially when they think they are being watched, but they seem less willing to act selflessly when there are religious or non-religious others who might benefit. ${ }^{83}$ A recent analysis of social attitudes in 33 countries found several interesting correlations among variables related to religiosity, nastiness (defined in relation to readiness to cause pain for the satisfaction of doing harm) and morality (defined in relation to conformity to conventional standards of moral conduct). Western European countries, which are by far the most secular, have the lowest scores on all three factors. ${ }^{84}$ In other words, in these contexts populations are more likely to be characterized by less parochial prosociality, less malicious aggression, and less shared imaginative engagement with supernatural agents.

Religious institutions have been around for such a long time, and are so deeply entangled with technologies that prime prosociality, that many people have become convinced that only they can produce morality. When it comes to real world altruism, however, religiosity in general does not seem to have any positive impact. For example, a well-known study of those who helped hide

8o Putnam, Bowling Alone: The Collapse and Revival of American Community (New York: Simon \& Schuster, 2001); Putnam and Campbell, American Grace: How Religion Divides and Unites Us (New York: Simon \& Schuster, 2012).

81 Sablosky, "Does Religion Foster Generosity?" Social Science Journal 51, no. 4 (2014).

82 For an overview, see Mitkidis and Levy, "False Advertising: The Attractiveness of Religion as a Moral Brand," in The Attraction of Religion: A New Evolutionary Psychology of Religion ed. Slone and van Slyke (Bloomsbury Academic, 2015).

83 Andreoni et al., "Diversity and Donations: The Effect of Religious and Ethnic Diversity on Charitable Giving," Journal of Economic Behavior and Organization 128 (2016).

84 Stankov and Lee, "Nastiness, Morality and Religiosity in 33 Nations," Personality and Individual Differences 99 (2016). 
or rescue Jews during the Holocaust found that the moderately religious were predominantly non-rescuers. Most rescuers were either highly religious or non-religious, leading researchers to conclude that other factors like nonconformity or social responsibility were better predictors of altruistic behavior. ${ }^{85}$ However, another more recent study of rescuers, which dealt with more variables in a broader statistical analysis, found that "religiosity and altruism are negatively related; the less religious one is, the more likely she is to rescue." 86

One review of the literature on this topic concluded that "there is surprisingly little evidence for a moral effect of specifically religious beliefs." ${ }^{87} \mathrm{On}$ the contrary, a growing body of evidence indicates that not believing in God, while maintaining social affiliation with others, is better for you and promotes a broader sort of prosociality.8 ${ }^{88}$ As we have seen throughout this book, religion promotes parochial or assortative prosociality, the dark side of which is anxiety about and antagonism toward out-groups. Non-religious people are on average at least as altruistic as religious people and, more importantly, their arena of moral concern applies to a wider range of subjects. While statistical survey analysis shows a (weak) relation beween respondents' religiosity and "benevolence" (forgiveness, loyalty, etc.), this concern for the welfare of others does not extend to "universalism" (tolerance, protection, etc., for all people). ${ }^{89}$

Belief in God does predict in-group prosociality and parochialism, but it also has the simultaneous effect of decreasing universal concern for those outside one's group..$^{90}$ This group-focused morality prevalent among religious believers may be connected not only to anxiety about protecting their own coalition, but also to the detection errors discussed above and in Chapter 1 . Neuroanatomical evidence from scanning experiments and analysis of moral foundations questionnaires found that "increased adherence to group-focused moral foundations was associated with reduced ACC [anterior cingulate

85 Oliner and Oliner, The Altruistic Personality: Rescuers of Jews in Nazi Europe (New York: Touchstone, 1992).

86 Varese and Yaish, "The Importance of Being Asked: The Rescue of Jews in Nazi Europe," Rationality and Society 12, no. 3 (200o): 320. See also Beit-Hallahmi, "Morality and Immorality among the Irreligious," in Zuckerman, ed., Atheism and Secularity 1 (New York: Praeger, 2010).

87 Bloom, "Religion, Morality, Evolution," Annual Review of Psychology 63 (2012): 179.

88 For a review of this literature, see Galen, "Atheism, Wellbeing, and the Wager: Why Not Believing in God (With Others) Is Good for You," Science, Religion and Culture 2, no. 3 (2015).

89 Saroglou et al., "Values and Religiosity: A Meta-Analysis of Studies Using Schwartz's Model," Personality and Individual Differences 37, no. 4 (2004).

$90 \quad$ Galen et al., "Nonreligious Group Factors Versus Religious Belief in the Prediction of Prosociality," Social Indicators Research 122, no. 2 (2015). 
cortex] and lateral PFC [prefrontal cortex] gray matter ... [suggesting that] people who adhere more stongly to group-focused moral foundations may be less able to detect and resolve conflict." ${ }^{\text {11 }}$ This latter inference is based on the fact that reduced ACC volume renders individuals less able to detect conflicts and discrepancies, and reduced lateral PFC volume renders them less able to resolve unavoidable conflicts, such as those related to social change.

While religious believers are often motivated to act "morally" by visions of an eschatological future promised by a supernatural agent, non-believers tend to "focus their moral concerns on social justice and the here-and-now."92 $\mathrm{Al}$ though they are motivated by different social cues, and use different criteria for judging an action as moral, for our purposes here the most interesting difference between theists and non-theists is that the former "tend to direct their prosociality more parochially toward ingroup members," while the morality of the latter has a "more universal scope."93 A recent cross-national study found that household religiousness was inversely predictive of children's altruism, challenging the view that religiosity facilitates prosocial behavior and providing evidence that "the secularization of moral discourse will not reduce human kindness - in fact, it will do just the opposite." ${ }^{94}$ When it comes to resisting the parochial prosociality and out-group antagonism driven by religious credulity and conformity biases, atheists also seem to have the moral advantage..$^{95}$

Another body of evidence that supports the claim that people do not need religion to be moral comes from contemporary sociological analysis. A review of the Global Peace Index shows that it is "the least God-fearing nations that

91 Nash, et al., "Group-Focused Morality Is Associated with Limited Conflict Detection and Resolution Capacity: Neuroanatomical Evidence," Biological Psychology 123 (2017): 237. Emphasis added.

92 Caldwell-Harris, "Understanding Atheism/non-Belief as an Expected Individual-Differences Variable," Religion, Brain \& Behavior 2, no. 1 (2012): 4.

93 Shariff et al., "Morality and the Religious Mind:Why Theists and Nontheists Differ," Trends in Cognitive Sciences 18, no. 9 (2014): 439. Emphasis added.

94 Decety et al., "The Negative Association between Religiousness and Children's Altruism across the World," Current Biology 25, no. 22 (2015): 3. Even critics of this controversial study concede that its dataset does reveal that generosity is (weakly) negatively correlated to frequency of household religious attendance and intrinsic religiosity: Shariff et al., "What Is the Association between Religious Affiliation and Children's Altruism?" Current Biology 26, no. 15 (2016).

95 The difference in the ability of religious and non-religious individuals to contest implicit in-group biases has also been detected in neuroscientific experiments. See, e.g., Huang and Han, "Shared Beliefs Enhance Shared Feelings: Religious/irreligious Identifications Modulate Empathic Neural Responses," Social Neuroscience 9, no. 6 (2014). 
enjoy the greatest levels of peace. ....among the top ten most peaceful nations on earth, all are among the least God-believing - in fact, eight of the ten are specifically among the least theistic nations on earth. Conversely, of the bottom ten - the least peaceful nations - most of them are extremely religious."96 When it comes to factors like women's rights, gay rights, and protecting the environment, "secular people actually possess a stronger or more ethical sense of social justice than their religious peers ... atheists and secular people are also the least likely to harbor ethnocentric, racist, or nationalist attitudes."97

As we have seen, these other forms of prejudice are reinforced by theism, and so it ought not to surprise us that atheists in general are less prone to sexism, classism, and racism. But what about the death and destruction caused by non-religious totalitarian regimes in the 2oth century? All non-democratic regimes - religious or irreligious - have led to less than ideal living conditions for the members of the societies they oppressed. We can all agree that totalitarianism is bad, regardless of how it is justified. When we remove this factor and focus on the relation between social well-being and (ir)religiosity, "the least religious democracies fare better on nearly all indicators of social well-being." ${ }^{98}$ Moreover, a recent analysis of a data set of over 700 ethnic groups in over 130 states found that religious identification was likely to contribute to the onset of civil war between ethnic group dyads, while atheist identification was not. ${ }^{99}$

Like secular democracies, atheist communities are a relatively new human experiment. Non-believers are certainly not immune to sexist, classicist, and racist biases. As we have seen, however, in general they are better at learning how to contest them. Increasingly, atheists are organizing, awakening to these and other concerns, and struggling to build even more just societies. ${ }^{100}$ As the

96 Zuckerman, Living the Secular Life, 2014, 47. See also Zuckerman, Society without God: What the Least Religious Nations Can Tell Us About Contentment (New York: NYU Press, 2010), 183, and Zuckerman, Faith No More: Why People Reject Religion (New York: Oxford University Press, 2011).

97 Zuckerman, "Atheism, Secularity, and Well-Being: How the Findings of Social Science Counter Negative Stereotypes and Assumptions," Sociology Compass 3, no. 6 (2009): 954.

98 Zuckerman et al., The Nonreligious, p. 86. For detailed analysis of these indicators see Paul, "The Evolution of Popular Religiosity and Secularism: How First World Statistics Reveal Why Religion Exists, Why It Has Been Popular, and Why the Most Successful Democracies Are the Most Secular," in Atheism and Secularity, 1, ed. Zuckerman (New York: Praeger, 2010).

99 Bormann et al., "Language, Religion, and Ethnic Civil War," Journal of Conflict Resolution 61, no. 4 (2017).

100 Cimino et al., Atheist Awakening: Secular Activism and Community in America (New York: Oxford University Press, 2014); Cimino and Smith, "Atheism, Class, and the Ghost of Karl 
non-religious "come out of the closet," the prejudice against them is beginning to diminish, albeit slowly. Around the globe, atheists are coming together, developing new ways to respond to the maladaptive effects of theistic credulity and conformity biases, and learning how to take care of each other as well as religious others. ${ }^{101}$

It is also important to emphasize the role of contextual variance in shaping the relationship between atheism and altruistic behavior. Atheist identities can be expressed quite differently in various social contexts around the globe. ${ }^{102}$ The well-being and moral flourishing of non-believers depends in large part on the social situation in which they find themselves. When surrounded by an oppressive religious majority, it is hardly surprising that atheists are stressed by constant encounters with theists and so keep to themselves. On the other hand, in more open, benign societies, the pattern tends to be that the non-religious have more life satisfaction and general social-well being. ${ }^{103}$ One of the most significant variables that predicts a strong relation between low religiosity and well-being in a population is the proportion of the gross national product that a government spends on social welfare. ${ }^{104}$ In Scandinavian

Marx," in Sociology of Atheism, ed. Cipriani and Garelli, (Leiden: Brill, 2016); Ledrew, "Discovering Atheism: Heterogeneity in Trajectories to Atheist Identity and Activism," Sociology of Religion 74, no. 4 (2013); Kettell, "Divided We Stand: The Politics of the Atheist Movement in the United States," Journal of Contemporary Religion 29, no. 3 (2014); Kettell, "Faithless: The Politics of New Atheism," Secularism and Nonreligion 2 (2013).

101 Smith and Cimino, "Atheisms Unbound: The Role of the New Media in the Formation of a Secularist Identity," Secularism and Nonreligion 1 (2012); Thiessen and Wilkins-Laflamme, "Becoming a Religious None: Irreligious Socialization and Disaffiliation," Journal for the Scientific Study of Religion 56, no. 1 (2017); Smith, "Creating a Godless Community: The Collective Identity Work of Contemporary American Atheists," Journal for the Scientific Study of Religion 52, no. 1 (2013); Sumerau and Cragun, "I Think Some People Need Religion': The Social Construction of Nonreligious Moral Identities," Sociology of Religion 77, no. 4 (2016); Sumerau et al., "An Interactionist Approach to the Social Construction of Deities," Symbolic Interaction 39, no. 4 (2016).

102 Beaman, Atheist Identities - Spaces and Social Contexts, (Springer International Publishing, 2014); Zuckerman, ed., Atheism and Secularity: Global Expressions. Vol 2. (New York: Praeger, 2010).

103 Diener et al., "The Religion Paradox: If Religion Makes People Happy, Why Are So Many Dropping Out?" Journal of Personality and Social Psychology 101, no. 6 (2011).

104 Scheve et al., "Religion and Preferences for Social Insurance," Quarterly Journal of Political Science 1, no. 3 (2006). For a discussion of the psychological implications of these correlations, see Granqvist, "Mental Health and Religion from an Attachment Viewpoint: Overview with Implications for Future Research," Mental Health, Religion \& Culture 17, no. 8 (2014). 
countries like Norway, it is often the irreligious who have more positive experiences of social support and caring interaction. ${ }^{105}$

None of this should be taken to imply that religious individuals are "bad," any more that the previous section should be taken to imply that they are "dumb." The empirical studies we have been exploring shed light on cognitive and coalitional mechanisms that are manifested in quite different ways at the individual and population levels. Any particular theist you meet on the street may be far more intelligent and altruistic than the atheist walking next to her. And if you were to transplant either of them to a new context, their individual beliefs and behaviors might change considerably. However, that does not challenge the basic claims that emerge from all of this research. Generally speaking, anthropomorphically promiscuous tendencies lead people to make more errors when trying to explain perceptually ambiguous natural phenomena. Generally speaking, sociographically prudish tendencies lead people to avoid risky altruism toward morally ambiguous out-group members.

\section{The Reciprocal Reinforcement of Theolytic Mechanisms}

Happily, efforts at contesting these evolved biases by promoting either naturalism or secularism benefit from a spiraling interaction that intensifies their god-dissolving effectiveness. ${ }^{106}$ When integrated, these theolytic forces create a trajectory that is diametrically opposed to the one produced by the god-bearing mechanisms operative in religious sects (Figure 3; compare to Figure 1, p. 3). In other words, pursuing anthropomorphically prudish explanations of nature and endorsing sociographically promiscuous inscriptions of society can also be reciprocally reinforcing.

We have already seen a great deal of warrant for this claim. As a sort of inversion of the third main hypothesis of theogonic reproduction theory, it is supported by much of the same evidence provided for the latter. This is particularly true for many of the survey data studies we have reviewed. If statistical analysis reveals that higher religious belief is correlated with lower support for broad governmental social care, for example, one can just as easily say it the other way around: lower religious belief is correlated with higher support. In other words, if naturalism and secularism really reinforce one another, then

\footnotetext{
105 Kvande et al., "Religiousness and Social Support: A Study in Secular Norway," Review of Religious Research 57, no. 1 (2015).

106 It is important to keep in mind that in this context I am continuing to use the terms naturalism and secularism in the sense introduced at the end of Chapter 1.
} 


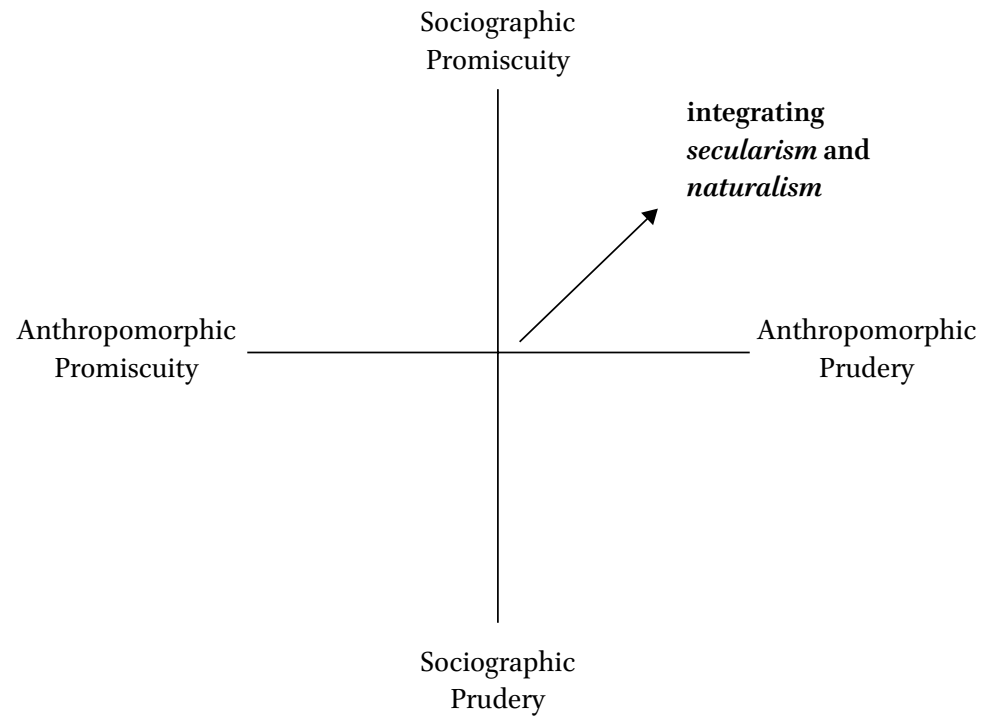

FIGURE 3 Integrating secularism and naturalism

we would expect the data to show exactly what we find: a strong correlation between variables related to disbelief in supernatural agents and variables related to dissaffection for supernatural authorities.

But do we also have evidence that there are causal relationships between some of the components of anthropomorphic prudery and sociographic promiscuity? Here too we can take the evidence from the priming and other experimental studies cited throughout this book as indirect support. In other words, if highly religious people are generally more likely to show aggression toward out-group members when mortality salience is triggered, for example, the converse also follows: less- or non-religious people are generally less likely to respond in that way. I leave it to the reader to review those studies again with the hypothesis about the mutual amplification of theolytic mechanisms in mind. However, we also have evidence that more directly supports the claim that these god-dissolving tendencies strengthen one another.

For example, one recent set of priming experiments tested the hypothesis that thinking about "science," which is at least methodologically naturalistic, and contains the idea of "broader moral vision of a society in which rationality is used for the mutual benefit of all," has a causal impact on moral judgments and behavior. It turns out that triggering thoughts about science can positively impact moral attitudes, such as responses to interpersonal violations and prosocial intentions. A post-experimental manipulation (playing an economics dictator game) revealed that priming naturalistic thoughts affected actual 
moral behaviors as well (leading to less economic exploitation). ${ }^{107}$ Another study attempting to replicate these findings found that both priming words related to science in general and words related to science as a secular authority increased moral sensitivity. ${ }^{108}$ Experiments involving young adults have found a somewhat automatic opposition between evaluations of explanations that use science and those that use God. These results indicate that "using scientific theories as ultimate explanations can serve as an automatic threat to religious beliefs, and vice versa."109

Analytic cognitive style predicts not only less belief in supernatural agents, as we saw above, but also less religious engagement (e.g., attendance or affiliation), an effect which one study found to be mediated through lower accepance of conventional religious beliefs. ${ }^{110}$ Science, which is based on the analysis of naturalistic explanations of causal mechanisms, can provide people with a sense of order and predictability. Experimental studies suggest that it is at least as effective as religion in helping individuals regulate their responses to external threats, while simultaneously reducing their reliance on supernatural agents to make sense of and organize their social worlds. ${ }^{111}$ Priming people with secular arguments that included claims that the world can be explained naturalistically through evolutionary theory lowered their explicit self-reports of religious belief - as well as measures of their implicit religiosity. ${ }^{112}$ These sorts of empirical studies indicate that some of the components of sociographic promiscuity and anthropomorphic prudery have a direct and mutually intensifying relationship.

Another type of evidence for this reciprocity comes from social sciences like economics and sociology. We have already noted several cross-national studies that show religiosity tends to decline as the quality of life in a country

107 Ma-Kellams and Blascovich, "Does 'Science' Make You Moral? The Effects of Priming Science on Moral Judgments and Behavior," PLoS ONE 8, no. 3 (2013).

108 Yilmaz and Bahçekapili, "When Science Replaces Religion: Science as a Secular Authority Bolsters Moral Sensitivity," PLoS ONE 10, no. 9 (2015).

109 Preston and Epley, "Science and God: An Automatic Opposition between Ultimate Explanations," Journal of Experimental Social Psychology 45, no. 1 (2009): 240.

110 Pennycook et al., "Analytic Cognitive Style Predicts Religious and Paranormal Belief," Cognition 123, no. 3 (2012): 335 .

111 Rutjens et al., "Step by Step: Finding Compensatory Order in Science," Current Directions in Psychological Science 22, no. 3 (2013), 250, 253. See also Rutjens et al., "Deus or Darwin: Randomness and Belief in Theories about the Origin of Life," Journal of Experimental Social Psychology 46, no. 6 (2010): 1080.

112 Shariff et al., "The Devil's Advocate: Secular Arguments Diminish Both Implicit and Explicit Religious Belief," Journal of Cognition and Culture 8, no. 3-4 (2008). 
increases. The results of a recent study of the relationship between religiosity and economic development within each of the 50 U.s. states were consistent with these findings: state religiosity declines as the quality of life improves. The authors conclude that "religion may thus function as an adaptive emotional response to difficult living conditions."113 These findings are also consistent with economic theories about the mechanisms of secularization. For example, one recent mathematical model predicts that if the marginal utility of secular leisure increases with more income availability, wealthier individuals who have higher cognitive abilities will be more likely to abandon "intuitive-believing" for "reflective-analytical" cognitive styles, which has a long-term positive effect on secularization. . $^{14}$

Even the presence of diverse marketing brands and their availability as tools for self-expression seems to have a negative impact on individual's self-reports (and demonstrations) of religious commitment. ${ }^{115}$ As religion loses its authority in large secularized societies, and becomes marginalized as a matter of "personal preference over which the community and the state have no right of judgment," it can easily become something of a "consumer good like cars and toothpaste."116 Secularization, in the sense in which I am using the term, tends to be found in contexts that are characterized not simply by economic growth, but also by lower income disparity (and other forms of psycho-sociological dysfunction). The fact that every first world country that has universal health coverage also has low religiosity is no coincidence. "[T]here is a direct cause and effect mechanism in which pragmatic secular progressive socioeconomic polices that use government assistance to modulate capitalism suppress mass faith by suppressing the economic and societal disparity and insecurity that mass religion depends on."117

113 Barber, "Why Is Mississippi More Religious Than New Hampshire? Material Security and Ethnicity as Factors," Cross-Cultural Research 49, no. 3 (2015): 323.

114 Strulik, "An Economic Theory of Religious Belief," Journal of Economic Behavior and Organization 128 (2016).

115 Cutright et al., "Finding Brands and Losing Your Religion?" Journal of Experimental Psychology: General 143, no. 6 (2014).

116 Bruce, "Authority and Freedom: Economics and Secularization," in Religions as Brands: New Perspectives on the Marketization of Religion and Spirituality, ed. Usunier and Stolz (Surrey, U K: Ashgate, 2014): 203.

117 Paul, "The Evolution of Popular Religiosity and Secularism: How First World Statistics Reveal Why Religion Exists, Why It Has Been Popular, and Why the Most Successful Democracies Are the Most Secular," 175-176, emphasis added. See also Paul, "The Chronic Dependence of Popular Religiosity upon Dysfunctional Psychosociological Conditions." 
If some mechanisms that promote sociographic promiscuity had a direct and positive causal impact on anthropomorphic prudery, we would also expect to find evidence that a high level of exposure to secularism during childhood or adolescence would predict higher levels of naturalism during adulthood. This is what we do find. Regression analyses of survey data show that individuals who had exposure to "credibility enhancing displays" (CREDs) in their families of origin were far more likely to have supernatural agent beliefs later in life. Conversely, individuals who were "exposed to especially low levels of religious CREDS were most likely to currently report a lack of belief in God with high certainty."118 Another recent study using priming manipulation techniques and a dictator game reported similar results. ${ }^{119}$ This indicates that a sociographically promiscuous social network can have a causal effect on individual anthropomorphic prudery. The causal connection between these theolytic forces is further confirmed by studies showing that young people with secular backgrounds are more likely to commit themselves to a (naturalistic) academic life. ${ }^{120}$

The impact of secular contexts on naturalistic tendencies is evident already in childhood. Experimental studies have shown, not too surprisingly, that children raised in religious backgrounds are far more likely to judge a protagonist in a religious story to be a real person, whereas secular children will tend to regard them as fictional. Perhaps more surprisingly, the inability to differentiate fact from fiction carries over into the interpretation of generally fantastical (not explicitly religious) narratives. Psychological experiments have also shown that children from non-religious backgrounds are much better at identifying fictional characters. From this, researchers have concluded that "it is more plausible that a religious upbringing overcomes children's pre-existing doubts about whether ordinarily impossible events can occur than that a secular upbringing suppresses children's natural inclination toward credulity." ${ }^{\prime 21}$

118 Lanman and Buhrmester, "Religious Actions Speak Louder than Words," Religion, Brain \& Behavior 7, no.1 (2015): 10. See also Lanman, "The Importance of Religious Displays for Belief Acquisition and Secularization," Journal of Contemporary Religion 27, no. 1 (2012): 57.

119 Hitzeman and Wastell, "Are Atheists Implicit Theists?" Journal of Cognition and Culture 17, no. 1-2 (2017).

120 Beit-Hallahmi, "Explaining the Secularity of Academics: Historical Questions and Psychological Findings," Science, Religion and Culture 2, no. 3 (2015).

121 Corriveau et al., "Judgments About Fact and Fiction by Children From Religious and Nonreligious Backgrounds," Cognitive Science 39, no. 2 (March 1, 2015): 375. See also Davoodi 
The results of another study focusing on five-year olds indicated that children are likely to consider religious stories about miracles or prophecies as "nothing more than fantastical events such as anthropomorphic animals that are featured in fairy tales" unless they are "inculcated with religious sentiments and information by adults." ${ }^{122}$ Children have traditionally been considered naturally gullible, becoming suspicious through experience over time. When it comes to fantasy figures in religious stories, however, psychological evidence suggests that younger children are more skeptical but become credulous as they get older - an effect amplified by family religiosity. ${ }^{123}$ In other words, children are normally born with extremely sensitive agency detection mechanisms, but they may only falsely detect supernatural agents (i.e. become anthropomorphically promicuous in the religious sense) if they are regularly primed by sociographically prudish parents and priests. Conversely, children raised by secular parents are more likely to be better at distinguishing between enjoyable fantasies and fiction, on the one hand, and naturalistic explanations of the world, on the other.

There also seems to be a "hydraulic relation" between people's beliefs in religious sources of control (e.g., supernatual agents) and their perception of governmental instability. Chronic or fluctuating levels of perceived lack of control can increase individual's levels of support for either governmental or religious systems, which indicates that both can serve as compensatory systems of control. ${ }^{124}$ Evidence from China revealed a "substitution effect" between strong legal institutions and the prevalence of religion in a region; both variables predict reduced corruption. ${ }^{125}$ Experimental manipulation studies have shown that triggering perceptions of the instability of government leads to increases in belief in God. When God is depicted as a source of order

et al., "Distinguishing between Realistic and Fantastical Figures in Iran" Developmental Psychology 52, no. 2 (2016).

122 Kotaman and Tekin, "The Impact of Religion on the Development of Young Children's Factuality Judgments," North American Journal of Psychology 17, no. 3 (2015): 8.

123 See, e.g., Woolley and Cox, "Development of Beliefs about Storybook Reality," Developmental Science 10, no. 5 (2007); Vaden and Woolley, "Does God Make It Real? Children's Belief in Religious Stories from the Judeo-Christian Tradition," Child Development 82, no. 4 (2011).

124 Kay et al., "God and the Government: Testing a Compensatory Control Mechanism for the Support of External Systems.," Journal of Personality and Social Psychology 95, no. 1 (2008): 18, and Kay et al., "Religious Belief as Compensatory Control," Personality and Social Psychology Review 14, no. 1 (2010).

$125 \mathrm{Xu}$ et al., "Does Religion Matter to Corruption? Evidence from China," China Economic Review 42 (2017). 
and control, participants in a North American study were less likely to defend the legitimacy of their governments. Conversely, "increased perceptions of political stability led to weaker beliefs in a controlling God."126 All of these findings support the idea that some of the component mechanisms that promote naturalism and secularism are causally linked in reciprocally reinforcing relationships.

As we have seen throughout this book, it is important to account for the way in which personal and situational variances mediate (or moderate) these kinds of relationships. For example, one study found that an individual's level of religious belief shapes the extent to which mortality salience leads to an increase in belief in "social-moral" progress. The researchers concluded that whereas more religious (especially Protestant) individuals might "focus on the promise of a better world in the form of a supernatural hereafter," when less religious individuals are prompted to search for existential meaning they can be triggered to focus on a better future world here and now. ${ }^{127}$ Contextual differences matter too. Regression analyses of data from 137 countries showed that disbelief in God increased in contexts where the human population acquired greater existential security, measured by factors such as economic development, proportion of people enrolled in higher education, health security, and more equal distribution of income. ${ }^{128}$

Scandinavian countries are often held up as exemplars of societies that promote safe sects. These contexts are among the least religious on the planet, and yet their people

enjoy high levels of existential security, strong and stable governments with social safety nets, and they no longer witness passionate displays of religiosity in the public sphere. These factors were likely mutually reinforcing: increases in existential security reduced motivations to attend religious services, in turn causing further declines of religious belief, leading to a cascade of irreligion. Furthermore, these societies have gradually and successfully replaced religion with effective secular institutions that encourage cooperation and enjoy very high levels of science education,

126 Kay et al., "For God (or) Country: The Hydraulic Relation Between Government Instability and Belief in Religious Sources of Control," Journal of Personality and Social Psychology 99, no. 5 (2010): 733-734.

127 Rutjens et al., "A March to a Better World? Religiosity and the Existential Function of Belief in Social-Moral Progress," The International Journal for the Psychology of Religion 26, no. 1 (2015).

128 Barber, "A Cross-National Test of the Uncertainty Hypothesis of Religious Belief," CrossCultural Research 45, no. 3 (2011). 
which further encourages and reinforces analytic thinking that fosters religious skepticism. ${ }^{129}$

These countries are far from perfect. However, their inhabitants do experience higher levels of well-being and exhibit more universal prosocial behaviors than inhabitants of more religious countries. The safe(r) sects one finds in Scandinavian (and other secular) contexts is largely a consequence of high investments of energy into supporting educational policies that promote anthropomorphic prudery and social policies that promote sociographic promiscuity.

The reciprocally reinforcing quality of these efforts may help to explain why the "cascade of irreligion" appears to be spreading around the world. As we saw in Chapter 6, atheists have been around at least since the axial age. Until the last two or three centuries, however, they have always made up a very small percentage of the population. With the rise of modern science and the establishment of non-sectarian governments, their numbers have steadily increased. Historians are continuing to uncover the significant role that atheists played in the emergence and growth of more socially just organizations and in the production and acceptance of more materially adequate explanations. ${ }^{130}$ These developments, in turn, have made it far easier for people in a wide variety of contexts to make sense of the world and act sensibly in society without appealing to supernatural agents and authorities.

In 2007 it was estimated that non-believers in God numbered as high as 749 million worldwide, making them the fourth largest group after Christianity (2 billion), Islam (1.2 billion) and Hinduism (90o million). ${ }^{131}$ By 2014 the "Unaffiliated" had overtaken Hindus by climbing to over 1.1 billion, making up $16.45 \%$ of the world's population. ${ }^{132} \mathrm{~A}$ recent synthesis of research on cross-national trends shows that rates of religious attendance are declining or have "bottomed out" in most countries in Europe, the Americas (including the U.s.), Australia, and New Zealand. ${ }^{133}$ Measuring the rise of "non-religion" can be difficult, in

129 Norenzayan and Gervais, "The Origins of Religious Disbelief," 24. Emphases added.

130 Stephens, Imagine There's No Heaven: How Atheism Helped Create the Modern World (New York: Macmillan, 2014); Watson, The Age of Atheists: How We Have Sought to Live Since the Death of God (New York: Simon and Schuster, 2014).

131 Zuckerman, "Atheism: Contemporary Numbers and Patterns," in Martin, ed., The Cambridge Companion to Atheism (Cambridge University Press: 2007).

132 Pew Research Center, "The Future of World Religions: Population Growth Projections, 2010-2050" (Washington, DC: Pew Research Center, May 11, 2015). See also Win-Gallup, "Global Index of Religiosity and Atheism" (Win-Gallup, 2012).

133 Brenner, "Research Synthesis: Cross-National Trends in Religious Service Attendance," Public Opinion Quarterly 80, no. 2 (2016). For more specific analyses of the decline in the 
part because of terminological ambiguities; atheist, unaffiliated, unbeliever, and non-attender do not all mean the same thing. One of the most important tasks in the growing field of research on non-religion is the clarification and operationalization of terms. ${ }^{134}$ Moreover, in some countries saying you are a non-believer carries a death sentence, which can deter self-reports of atheism. Still, even in many places in the Arab world, for example, atheism is on the rise, even if less visibly. ${ }^{135}$

Segregative inscriptions based on superstitious interpretations of punitive (or rewarding) gods are becoming more and more problematic in our current pluralistic, globalizing environment. Younger people in particular seem far less interested in "doing it." Survey data on high school students indicates that the next generation of young adults will be even less approving of religious organizations and find religion even less important in their lives. ${ }^{136}$ In every country included in the European Social Survey, each new generation cohort reported being less religious than the last. ${ }^{137}$

The United States is not the exception some people consider it to be. In fact, American religiosity has been "declining for decades, and ... that decline has been produced by the same generational patterns that lie behind religious decline elsewhere in the West: each successive cohort is less religious than the preceding one."138 The American Religious Identification Survey showed

U.S. and Britain, see McCaffree, The Secular Landscape: The Decline of Religion in America (New York, Palgrave Macmillan, 2017), Bruce, "The Sociology of Late Secularization: Social Divisions and Religiosity," British Journal of Sociology 67, no. 4 (2016), and Bruce and Voas, "Do Social Crises Cause Religious Revivals? What British Church Adherence Rates Show," Journal of Religion in Europe 9, no. 1 (2016).

134 Lee, "Talking about a Revolution: Terminology for the New Field of Non-Religion Studies," Journal of Contemporary Religion 27, no. 1 (2012); Lee, "Non-Religion," in The Oxford Handbook of the Study of Religion, ed. Stausberg and Engler (New York: Oxford University Press, 2016); Bullivant, “Defining 'Atheism," in The Oxford Handbook of Atheism, ed. Bullivant and Ruse (New York: Oxford University Press, 2013); Cragun, "Defining That Which Is Other to Religion," in Religion: Beyond Religion, ed. Zuckerman (New York: Macmillan, 2016).

135 Benchemsi, "Invisible Atheists," New Republic 246, no. 4 (2015).

136 Twenge et al., "Generational and Time Period Differences in American Adolescents' Religious Orientation, 1966-2014," PLoS ONE 10, no. 5 (May 11, 2015).

137 Voas, "The Rise and Fall of Fuzzy Fidelity in Europe," European Sociological Review 25, no. 2 (2009): 167. See also Bruce, "Post-Secularity and Religion in Britain: An Empirical Assessment," Journal of Contemporary Religion 28, no. 3 (2013).

138 Voas and Chaves, "Is the United States a Counterexample to the Secularization Thesis?," American Journal of Sociology 121, no. 5 (2016): 1517. 
that less than a third of college students in 2013 self-identified as religious. ${ }^{139}$ Another recent study found that nearly $40 \%$ of young adults in America are religiously unaffiliated, which is three times the rate among seniors; this age gap has been widening for decades. ${ }^{140}$ Even more recently, analysis of the 2016 American Values Atlas showed that the unaffiliated make up the largest "religious" group in the U.s. (at $24 \%$, compared to the second largest group, white evangelical Protestants, at $17 \%) .{ }^{141}$

While non-believers in countries like the U.s. are not (usually) in danger of losing their lives for their lack of religiosity, the label "atheist" remains heavily stigmatized. In order to overcome the problem that some atheists might not be willing to disclose their disbelief in response to pollsters explicitly asking about "atheism," one recent study utilized Bayesian estimation analysis to generate an indirect estimate of the prevalence of atheism. The results indicated that as many as $26 \%$ of all Americans could be atheists, a percentage far higher than the $11 \%$ range typically reported by conventional polls. ${ }^{142}$

Is the spread of irreligiosity, fueled by the reciprocal reinforcement of anthropomorphic prudery and sociographic promiscuity, likely to continue? Whatever the answer may be, I hope that the scientific and philosophical perspectives I have summarized and presented in the preceding pages will convince many readers that the expansion of atheism is not as scary as our evolved cognitive and coalitional biases have led us to think. It turns out that most demographic models predict that the number of unbelievers (or unaffiliators) will continue to grow, even if birth rates (which strongly favor the religious) remain the same. ${ }^{143}$ Mathematical forecasting models, which can more easily include other parameters and be calibrated more precisely

139 Kosmin and Keysar, "Religious, Spiritual and Secular: The Emergence of Three Distinct Worldviews among American College Students," American Religious Identification Survey (Hartford, ст: Trinity College, 2013).

140 Jones et al., "Exodus: Why Americans Are Leaving Religion - and Why They're Unlikely to Come Back" (Washington, D.C.: Public Religion Research Institute, September 22, 2016). See also Funk and Smith, "Nones on the Rise: One-in-Five Adults Have No Religious Affiliation," (Washington: Pew Research Center, 2012).

141 Jones and Cox, "America's Changing Religious Identity" (Public Religion Research Institute, September 6, 2017), https://www.prri.org/wp-content/uploads/2017/og/PRRI -Religion-Report.pdf.

142 Gervais and Najle, "How Many Atheists Are There?" Social Psychological \& Personality Science., 2017.

143 See, e.g., Smith and Baker, American Secularism: Cultural Contours of Nonreligious Belief Systems (New York: NYU Press, 2015), 87, and the other demographic reports mentioned above. 
in relation to earlier datasets, tend to predict an even more rapid growth of non-religion. ${ }^{144}$

As we have seen throughout this book, however, the interactions among the many mechanisms at work in religious reproduction, and the variations manifested both at the micro-level of individuals and the macro-level of cultures, are exceedingly complicated. Understanding and explaining these interactions and variations requires insights and methodological tools from a multitude of academic disciplines. Managing all this complexity can be taxing on the human brain. The good news is that recent advances in computer modeling techniques are opening up new ways to explore complex adaptive social systems, thereby enhancing our predictive and adaptive capacities.

\section{The (Methodological) Joy of (Simulating) Sects}

Computational modeling and simulation techniques have been around for several decades, but their application within the social sciences really only began to take off in the 1980 s and $1990{ }^{145}$ During the first decade and a half of this century, the use of these sorts of methodologies has spread rapidly in a wide variety of disciplines, including biology, archaeology, cognitive science, economics, and sociology. ${ }^{146}$ The excitement around these developments is

144 See, e.g., Stinespring and Cragun, "Simple Markov Model for Estimating the Growth of Nonreligion in the United States," Science, Religion and Culture 2, no. 3 (2015), and Abrams et al., "Dynamics of Social Group Competition: Modeling the Decline of Religious Affiliation," Physical Review Letters 107, no. 8 (2011).

145 Axelrod, The Evolution of Cooperation, (New York: Basic Books, 1984); Axelrod, The Complexity of Cooperation: Agent-Based Models of Competition and Collaboration (Princeton University Press, 1997); Gilbert and Doran, Simulating Societies. The Computer Simulation of Social Phenomena, (London: UCL Press, 1994); Conte et al., "Introduction: Social Simulation - a New Disciplinary Synthesis," in Simulating Social Phenomena (Springer, 1997); Epstein and Axtell, Growing Artificial Societies: Social Science from the Bottom Up (New York: Brookings Institution Press, 1996); Kohler and Gumerman, Dynamics in Human and Primate Societies: Agent-Based Modeling of Social and Spatial Processes (Oxford University Press, 2000).

146 Wolfram, A New Kind of Science (Champaign, IL: Wolfram Media, 2002); Gilbert and Troitzsch, Simulation for the Social Scientist (Berkshire, UK: McGraw-Hill Education, 2005); Epstein, Generative Social Science: Studies in Agent-Based Computational Modeling (Princeton University Press, 2006); Sun, Cognition and Multi-Agent Interaction: From Cognitive Modeling to Social Simulation (Cambridge University Press, 2006); Squazzoni, Agent-Based Computational Sociology (New York: John Wiley \& Sons, 2012); Hamill and Gilbert, Agent-Based Modelling in Economics (New York:John Wiley \& Sons, 2015); Alvarez, 
due not only to the explanatory and predictive power of computer modeling and simulation, but also to the way in which such efforts raise new questions about (and provide new answers to) issues that bear on classical philosophical debates about epistemology, intelligibility, and rationality, as well as metaphysics, emergence, and causality. ${ }^{147}$ Its philosophical implications and scientific impact have even led some scholars to refer to computer modeling and simulation as the "third pillar" of science, alongside theory and experimentation. ${ }^{148}$

Like all innovative methodologies, the use of computational models and simulation experiments raises important ethical questions as well. Could this new technology be used in ways that could lead to more human suffering? Could a criminal mastermind (or mega-church pastor or totalitarian dictator) use simulations to manipulate large numbers of people? Modeling tools provide significantly more analytic and predictive power than the human race has had to deal with before and so these sorts of questions must be taken seriously. It is also important to acknowledge that people are already and always manipulating and being manipulated by simulations. This is how human thought and action work. Thinking about what to do (or what we would like others to do) necessarily involves the construction of mental models and simulations. This means that the latter are already at work in the engineering and policing of all human groups - including families, religious sects, and secular institutions.

One of the virtues of computational simulation methodologies, however, is that they only work well if one is exceptionally clear about the assumptions, inferences, mechanisms, implications, and intentions of the proposed model. As is the case with every other technological advancement, there is no guarantee that computer simulations will not be misused or abused, but at least the process by which successful models are constructed invites critical analysis and debate. Throughout this book we have explored a wide array of mechanisms (at multiple levels of analysis) that operate within complex adaptive theogonic systems. Given all of this multiplicity and complexity, computational

ed., Computational Social Science: Discovery and Prediction (Cambridge University Press, 2016).

147 See, e.g., Squazzoni, Epistemological Aspects of Computer Simulation in the Social Sciences (Springer, 2009); Winsberg, Science in the Age of Computer Simulation (University of Chicago Press, 2010); DeLanda, Philosophy and Simulation: The Emergence of Synthetic Reason (Bloomsbury Publishing, 2011); Tolk, ed. Ontology, Epistemology, and Teleology for Modeling and Simulation (Springer, 2013).

148 Yilmaz, ed., Concepts and Methodologies for Modeling and Simulation (New York: Springer, 2015); others refer to these developments as initiating a "fourth paradigm" for science; see Hey et al., The Fourth Paradigm: Data-Intensive Scientific Discovery (Redmond, Wash.: Microsoft Research, 2009). 
methodologies may be one of our best options for fostering an open dialogue about the way in which god-bearing mechanisms have shaped human life in the past - and about the ways in which naturalism and secularism may shape human life in the future.

In addition to forcing more conceptual clarity and offering more computational processing power, modeling and simulation methodologies have several other virtues, including providing the capacity

- to develop causal architectures that incorporate the dynamics of both micro- and macro-level mechanisms,

- to construct and execute experiments in artificial societies that would not otherwise be feasible or ethical,

- to explain the emergence of a complex social phenomenon by "growing it" from the bottom-up,

- to integrate insights from qualitative and quantitative research within the same computational model,

- to shift the burden of proof in long-standing theoretical debates about the causal dynamics at work in historical events, and

- to explore the dynamic possibility space of a social system in order to determine the parametric and probabilistic conditions for specific configurations.

These are some of the reasons why computational modeling and simulation are so valuable when it comes to dealing with phenomena as complex and important as (non)religion.

The appropriation of these new methodologies to analyze and explore the mechanisms at work in the emergence, development, and dissolution of religious beliefs and behaviors is relatively recent. However, interest in their explanatory power and potential within the relevant fields is growing rapidly. ${ }^{149}$ Several of the early applications of computer modeling to issues related to religion produced simulations of the dynamics involved in shifts in religious faith and prejudice in human populations. ${ }^{150}$ Over the years a variety

149 See, e.g., Nielbo et al., "Computing Religion: A New Tool in the Multilevel Analysis of Religion," Method and Theory in the Study of Religion 24, no. 3 (2012): 271, and Lane, "Method, Theory, and Multi-Agent Artificial Intelligence: Creating Computer Models of Complex Social Interaction," Journal for the Cognitive Science of Religion 1, no. 2 (2014).

150 For a review, and several examples, see Bainbridge, God from the Machine: Artificial Intelligence Models of Religious Cognition (Lanham, MD: AltaMira Press, 2006), and Bainbridge, "Artificial Intelligence Models of Religious Evolution," in Evolution, Religion and Cognitive Science, ed. Watts (Oxford: Oxford University Press, 2014). See also Iannaccone and Makowsky, "Accidental Atheists? Agent-Based Explanations for the Persistence of 
of computational models have explored other aspects of religion, including mechanisms that contribute to what I have been referring to as anthropomorphic promiscuity and sociographic prudery. Simulation methodologies have provided new insights into the operation and transmission of these evolved cognitive and coalitional tendencies, including the error and risk management strategies that characterize religious imagination, ritual practices, and social networks. ${ }^{151}$ These insights in turn have contributed to the refinement of classical and contemporary theories of religion, as well as the generation of new hypotheses for investigation in future empirical research.

The international network of scholars interested in applying these methodologies within the scientific study of religion continues to grow. For example, several interrelated research projects utilizing computational modeling and simulation methods are currently underway as part of a collaboration between the Center for Modeling Social Systems in Kristiansand, Norway, the Center for Mind and Culture in Boston, Massachusetts, and the Virginia Modeling, Analysis, and Simulation Center in Suffolk, Virginia. Our team has already developed several system-dynamics models of the role of religion in major transformational periods in human civilization, including the Neolithic

Religious Regionalism," Journal for the Scientific Study of Religion 46, no. 1 (2007). For examples of the application of computer modeling to the study of phenomena more generally related to cooperation within and competition among religions, see Upal, "The Structure of False Social Beliefs," Proceedings of the 2007 IEE E Symposiun on Artificial Life (2007), Lindström and Olsson, "Mechanisms of Social Avoidance Learning Can Explain the Emergence of Adaptive and Arbitrary Behavioral Traditions in Humans," Journal of Experimental Psychology: General 144, no. 3 (2015), Sun and Fleischer, "A Cognitive Social Simulation of Tribal Survival Strategies: The Importance of Cognitive and Motivati onal Factors," Journal of Cognition and Culture 12, no. 3-4 (2012), Choi et al., "The Coevolution of Parochial Altruism and War," Science 318, no. 5850 (2007), and Chiang, "Good Samaritans in Networks: An Experiment on How Networks Influence Egalitarian Sharing and the Evolution of Inequality," PLoS ONE 10, no. 6 (2015).

151 Nielbo and Sørensen, "Attentional Resource Allocation and Cultural Modulation in a Computational Model of Ritualized Behavior," Religion, Brain \& Behavior 6, no. 4 (2016); Whitehouse et al., "The Role for Simulations in Theory Construction for the Social Sciences: Case Studies Concerning Divergent Modes of Religiosity," Religion, Brain \& Behavior 2, no.3 (2012); Dávid-Barrett and Carney, "The Deification of Historical Figures and the Emergence of Priesthoods as a Solution to a Network Coordination Problem," Religion, Brain \& Behavior, 6, no. 4 (2016); Roitto, "Dangerous but Contagious Altruism: Recruitment of Group Members and Reform of Cooperation Style through Altruism in Two Modified Versions of Hammond and Axelrod's Simulation of Ethnocentric Cooperation," Religion, Brain \& Behavior 6, no. 2 (2016); Matthews et al., "Cultural Inheritance or Cultural Diffusion of Religious Violence? A Quantitative Case Study of the Radical Reformation," Religion, Brain \& Behavior 3, no. 1 (2013). 
transition (to agriculture and sedentation), the axial age transition (to largescale cultures involving priestly elites), and the modernity transition (to less reliance on supernatural beliefs). ${ }^{152}$

We are also working on a series of agent-based models that simulate and explore the mechanisms at work in religious belief and behavior. Our goal is to develop a standard computational model of religious cognition. This will involve the construction of several component models, each of which will simulate a major theory that deals with an important mechanism (or set of mechanisms) at work in religion. The first step was developing a computational model of terror management theory, in which we we were able to simulate the dynamic interaction between mortality salience and religiosity (discussed in Chapter 1 above). Our simulation experiments were able to "grow" the complex phenomena studied by that theory, to replicate the findings of other psychological experiments on terror management, and to identify new patterns in these dynamics that had previously not been detected. ${ }^{153}$ The second step was a model that could simulate the dynamics of intergroup conflict, allowing us to shed light on some of the parametric conditions under which mutually escalating religious violence can emerge. ${ }^{154}$

We are currently developing other models that aim to simulate the cognitive and coalitional dynamics analyzed by several other influential theories in the scientific study of religion discussed in the preceeding chapters, including identity fusion theory, sacred values theory, costly signaling theory, ritual competence theory, and ritual modes theory. Some of our projects are explicitly oriented toward developing computational models that are relevant for public policy discussions about the role of religion and secularization in contemporary societies. Intergroup conflicts that are based on (or amplified by) differences among religious groups have contributed to mass migration, refugee crises, and challenges related to the integration of immigrants into pluralistic contexts. Our goal is to utilize simulation methodologies to shed light on the causes (and effects) of these cultural phenomena, and to provide new computational tools for evaluating hypotheses about - and policies for - societal change.

$15^{2}$ See Shults and Wildman, "Modeling Çatalhöyük: Simulating Religious Entanglement and Social Investment in the Neolithic," in Religion, History and Place in the Origin of Settled Life, ed. Hodder (Colorado Springs, co: University of Colorado Press, in press). Publications based on the other systems-dynamics models are under review.

153 See Shults et al., "Modeling Terror Management Theory: Computer Simulations of the Impact of Mortality Salience on Religiosity" Religion, Brain \& Behavior 8, no. 1 (2018).

154 Shults et al., "Mutually Escalating Religious Violence: A Generative and Predictive Computational Model," Social Simulation Conference Proceedings, 2017. 
Another set of models are aimed more explicitly at simulating the conditions under which - and the mechanisms by which - variables related to naturalism and secularism can be promoted within human populations. The first of these involved the construction of a computational architecture with simulated agents whose variables include supernatural belief, religious practice, belief in God, level of education, and felt existential security. The initial distribution of these variables (at the beginning of each simulation) was based on exploratory factor analyses and structural equation models grounded in the International Social Survey Programme data set, and country level analyses of well-being and existential security from the Human Development Report. Validation of these experiments showed that our agent-based model was up to three times more accurate in predicting the real-world rise and fall of the relevant variables than its nearest competitor (generalized linear regression analysis). ${ }^{155}$

The capacity of our model to "grow" a macro-level shift toward non-religiosity in a population, a shift that is generated by (or emergent from) micro-level agent behaviors and social network interactions, strengthens the plausibility of the argument that education and existential security are mechanisms that promote atheism within a society. The next step is to expand this model to include variables related to cultural pluralism and freedom of expression, factors that have also been identified in the empirical literature as drivers of religious disbelief and disaffiliation. We are also in the process of constructing several other computer models of non-religion, which will try to shed light on the mechanisms that contribute to the emergence of higher proportions of analytic and altruistic atheists who are affiliated in healthy social networks within human populations, thereby promoting the sort of reflective naturalistic explanations and peaceful secular organizations necessary for addressing the serious adaptive challenges we face in our current global environment.

Can we learn to practice safe sects? Can we learn how to live together without bearing gods? For all of the reasons we have been exploring in this book, most people will strongly resist the dissolution of (their) religion. They will keep fighting (mentally or physically) to hold onto the supernatural agents ritually engaged by their religious in-groups. It is highly unlikely that an adaptive atheist strategy will be universally embraced any time soon. In fact, it is not at all clear whether there is a viable route to the widespread practice of safe sects. It is quite clear, however, that explicitly oppressing religion - or trying

155 For details, see Gore et al., "Forecasting Change in Religiosity and Existential Security with an Agent-Based Model," Journal of Artificial Societies and Social Simulation 21, no. 1 (2018), and Shults et al., "Why Do the Godless Prosper? Modeling the Cognitive and Coalitional Mechanisms That Promote Atheism," Psychology of Religion and Spirituality, forthcoming. 
to force people to repress their desire to engage in religious sects - will only make things worse. ${ }^{156}$ As we have seen, attacking religious beliefs or mocking religious behaviors can all too easily activate and amplify theistic credulity and conformity biases, which tragically lead to the further entrenchment of the worldview and in-group defense mechanisms that fuel resistance to naturalism and secularism.

What's an atheist to do? Our review of the empirical findings in the biocultural study of (non)religion suggests several promising strategies, such as providing existential security, better education, more encounters with ideological others, greater freedom of expression, and opportunities to reflect on the mechanisms by which gods are born(e) in minds and cultures. Like racism, classism, sexism, and other biases involving constructed realities, theism often begins to dissolve when people start to understand the covert cognitive and coalitional tendencies that drive its operation and see the deleterious effects it has on human life. For many people, however, debiasing can only begin to happen when they (and those whom they love) feel safe and are given enough space, time, and encouragement to think through their options. This is why I have been calling for more of us to have "the talk" about religious reproduction, its causes and its consequences. No doubt some people will get offended when we start discussing the explicit details. Others will feel liberated. But we can't keep putting it off. This may be one of the most important conversations of our generation.

${ }_{15}$ Northmore-Ball and Evans, "Secularization versus Religious Revival in Eastern Europe: Church Institutional Resilience, State Repression and Divergent Paths," Social Science Research 57 (2016); Toft et al., God's Century: Resurgent Religion and Global Politics (Norton, 2011); Shah et al., Rethinking Religion and World Affairs (Oxford University Press, 2012); Grim and Finke, The Price of Freedom Denied: Religious Persecution and Conflict in the Twenty-First Century (Cambridge University Press, 2011). 